\title{
Distillation Designs for the Lunar Surface
}

\author{
Peter J. Boul ${ }^{1}$ \\ ERC Inc., Engineering and Science Contract Group, 2224 Bay Area Blvd., Houston, Tx. 77058 \\ Kevin E. Lange ${ }^{2}$ \\ Jacobs Engineering, Engineering and Science Contract Group, 2224 Bay Area Blvd., Houston, Tx. 77058 \\ Bruce Conger $^{3}$ \\ Hamilton Sundstrand, Engineering and Science Contract Group, 2224 Bay Area Blvd., Houston, Tx. 77058 \\ and \\ Molly Anderson ${ }^{4}$ \\ NASA-Johnson Space Center, Houston, Tx. 77058
}

\begin{abstract}
Gravity-based distillation methods may be applied to the purification of wastewater on the lunar base. These solutions to water processing are robust physical separation techniques, which may be more advantageous than many other techniques for their simplicity in design and operation. The two techniques can be used in conjunction with each other to obtain high purity water. The components and feed compositions for modeling waste water streams are presented in conjunction with the Aspen property system for traditional stage distillation. While the individual components for each of the waste streams will vary naturally within certain bounds, an analog model for waste water processing is suggested based on typical concentration ranges for these components. Target purity levels for recycled water are determined for each individual component based on NASA's required maximum contaminant levels for potable water

Optimum parameters such as reflux ratio, feed stage location, and processing rates are determined with respect to the power consumption of the process. Multistage distillation is evaluated for components in wastewater to determine the minimum number of stages necessary for each of 65 components in humidity condensate and urine wastewater mixed streams.
\end{abstract}

\section{Nomenclature}

$\begin{array}{ll}{ }^{\circ} \mathrm{C} & =\text { Degrees Celsius } \\ \mathrm{CDS} & =\text { Cascade Distiller Subsystem } \\ \mathrm{CGCC} & =\text { Column Grand Composite Curve } \\ \mathrm{Cm} & =\text { Centimeter } \\ \mathrm{CO}_{2} & =\text { Carbon Dioxide } \\ E P A & =\text { Environmental Protection Agency } \\ \mathrm{Ft} & =\text { Foot } \\ g & =\text { gram } \\ G C C & =\text { grand composite curve } \\ \mathrm{HCA} & =\text { Humidity Condensate Model A } \\ \mathrm{HETP} & =\text { Height Equivalent Theoretical Plate } \\ I S S & =\text { International Space Station } \\ J S C & =\text { Johnson Space Center } \\ k W & =\text { Kilowatt } \\ M C L & =\text { Maximum Concentration Level }\end{array}$

\footnotetext{
${ }^{1}$ Staff Scientist, ERC Inc., Engineering and Science Contract Group, 2224 Bay Area Blvd.. Houston, Tx. 77058.

${ }^{2}$ Project Engineer, Engineering and Science Contract Group, 2224 Bay Area Blvd.. Houston, Tx. 77058.

${ }^{3}$ Project Manager, Engineering and Science Contract Group, 2224 Bay Area Blvd.. Houston, Tx. 77058.

${ }^{4}$ ELS SIMA Element Lead, NASA-Johnson Space Center, Houston, Tx. 77058.
} 


$\begin{array}{ll}\mu g / L & =\text { Micrograms per Liter } \\ m L & =\text { Milliliter } \\ m m & =\text { Millimeter } \\ m / s & =\text { Meters per second } \\ N a O H & =\text { Sodium Hydroxide } \\ N A S A & =\text { National Aeronautics and Space Administration } \\ O_{2} & =\text { Oxygen } \\ P a & =\text { Pascal } \\ R D & =\text { Reactive Distillation } \\ V O C & =\text { Volatile Organic Compound } \\ W & =\text { Watt }\end{array}$

\section{Introduction}

$\mathrm{M}$ any designs for water purification feature disposable parts or processes that produce waste. For example, carbon dioxide $\left(\mathrm{CO}_{2}\right)$ removal with lithium hydroxide is an effective, but not readily regenerable process [1]. The reaction product of $\mathrm{CO}_{2}$ and lithium hydroxide is lithium carbonate, which makes this process non-regenerable. Biocatalytic processes are also less than favorable due to their high maintenance requirements. Distillation and air stripping are physico-chemical processes, which are robust and well established. This report evaluates the power consumptions, component removal feasibility, and scaling factors for the purification of wastewater on the lunar surface through these processes.

\section{Target Concentrations of Impurities}

The wastewater components described in the humidity condensate wastewater model A (HCA), and the urine wastewater described in a previous report [2], are identified in Table A and Table B. The procedure described for the distillation comparison test for mixing urine and humidity condensate was followed schematically such that 6.0 liters of urine wastewater and 7.8 liters of humidity condensate wastewater were mixed with the addition of Oxone ${ }^{\circledR}$ and sulfuric acid [3].

Appendix: Contaminant Concentration Specifications presents the National Aeronautics and Space Administration's (NASA's) required minimum contaminant levels for potable water (see Table A-1). To use these values, the organic alcohol components in the humidity condensate and urine condensate lists are grouped together and assigned to the value of maximum concentration of 500 micrograms per liter $(\mu \mathrm{g} / \mathrm{L})$. In order to calculate the maximum level for each individual alcohol component, the ratio of each alcohol to the total alcohol ratio was taken and multiplied by this maximum required level.

In the same manner as how the alcohols were assigned targets, the organic acids were grouped together and assigned a total maximum value of $500 \mu \mathrm{g} / \mathrm{L}$. The organic acid ratios to the total organic acid concentrations were multiplied by the maximum allowable concentration for the category of organic acids. In this way, the ratios of organic acids to one another were kept constant from the wastewater level to the purified water level.

Ammonia was given the described minimum value in the chart of 0.5 milligrams per liter $(\mathrm{mg} / \mathrm{L})$. The target diethyl phthalate concentration was defined as the maximum concentration level (MCL) set by the environmental protection agency (EPA). If the compounds indicated were not alcohols or organic acids, then the target concentration was set to 1 percent of the initial value (with the exception of creatinine and urea, which were set at 0.01 percent).

This technique for defining target concentrations makes the water requirements more stringent than those described by NASA. Using these targets for component concentrations, the parameters of a column are defined such that they will meet or exceed these requirements. These values are just guidelines for the development of a feasible model for water purification. The design assures that NASA standards for potable water purity will be met. 


\subsection{Humidity Condensate}

The target concentrations for HCA are defined as the same as for the mixed wastewater stream. This mixed stream serves as a model and a reference to the pretreatment of mixed wastewater streams used in the distillation comparison test. The target concentrations in the test are instructional so that the purified water will meet NASA's standard for wastewater.

While the comparison of designs in distillation will rely on the values for individual streams given by Table $\mathrm{B}$ and Table $\mathrm{C}$, the ultimate design of the system will be designed to meet the specifications set by Tables A-2 and A-3 in Appendix A. For the most part, the primary differences between Tables A and B in the main text and Tables A-2 and A-3 in Appendix A is that the components and their initial concentrations are

different. The target concentration for each component, however, is the same in all Tables. The complete system discussed in this report is designed purify a mixed stream of humidity condensate and urine wastewater such as that being studied in the cascade distiller subsystem (CDS) distillation tests at NASA Johnson Space Center (JSC) [3]. 


\section{Table A: Humidity Condensate A Components}

Note: These values come from an average of the occurrence through a number of Shuttle and Spacelab missions [4]. The flow rate for the feed stream was set at 10 kilograms per day (kg/day).

\begin{tabular}{|c|c|c|}
\hline $\begin{array}{l}\text { HCA Components } \\
\text { Component (alcohols are orange, organic } \\
\text { acids are pink) }\end{array}$ & $\begin{array}{l}\text { Concentration } \\
\mathrm{mg} / \mathrm{L}[2]\end{array}$ & $\begin{array}{c}\text { Target Concentration } \\
\text { (after purification) } \\
{[\mathrm{mg} / \mathrm{L}]}\end{array}$ \\
\hline 2-propanol & 46.3 & 0.024 \\
\hline 1,2-propanediol & 45.23 & 0.024 \\
\hline Ammonia & 18.04 & 0.5 \\
\hline Acetic acid & 14.61 & 0.0043 \\
\hline Caprolactam & 11.83 & 0.0066 \\
\hline Ethylene glycol & 10.22 & 0.0053 \\
\hline Glycolic acid & 10.19 & 0.0030 \\
\hline Ethanol & 8.181 & 0.0052 \\
\hline Formaldehyde & 8.136 & 0.046 \\
\hline Formic acid & 7.239 & 0.017 \\
\hline Propionic acid & 3.916 & 0.0012 \\
\hline Methanol & 3.737 & 0.0042 \\
\hline 4-ethyl morpholine & 2.516 & 0.014 \\
\hline Urea & 2.415 & 0.0576 \\
\hline 4-hydroxy-4-methyl-2-pentanone & 1.247 & 0.070 \\
\hline 2-butoxyethoxyethanol & 1.13 & 0.00059 \\
\hline 4-acetyl morpholine & 1.092 & 0.0061 \\
\hline 1-butanol & 0.937 & 0.049 \\
\hline 2-butoxyethanol & 0.803 & 0.00042 \\
\hline Carbon disulfide & 0.785 & 0.0044 \\
\hline $\mathrm{N}, \mathrm{N}$-dimethylformamide & 0.608 & 0.0034 \\
\hline Hexanoic Acid & 0.582 & 0.00017 \\
\hline Dibutyl amine & 0.566 & 0.0032 \\
\hline 2-ethoxyethanol & 0.504 & 0.00026 \\
\hline Diethylphthalate & 0.499 & 0.006 \\
\hline Pentanoic acid & 0.441 & 0.00013 \\
\hline Morpholine & 0.384 & 0.0022 \\
\hline Butanoic acid & 0.37 & 0.00011 \\
\hline 2-ethyl Hexanoic Acid & 0.37 & 0.0021 \\
\hline 2-(2-ethoxyethoxy)ethanol & 0.354 & 0.00018 \\
\hline Acetone & 0.348 & 0.0020 \\
\hline 1-methyl-2-pyrrolidinone & 0.339 & 0.0019 \\
\hline Nonanoic acid & 0.335 & 0.0037 \\
\hline Isobutyric acid & 0.32 & 0.000094 \\
\hline $\begin{array}{l}\text { Lactic acid } \\
13 \text {-tri-2-nronenvl-1 35-triazine-2 } 46 \text { - }\end{array}$ & 0.32 & 0.084 \\
\hline $\begin{array}{l}\text { trione } \\
\text { trion }\end{array}$ & 0.296 & 0.0296 \\
\hline
\end{tabular}


Table B: Components for Urine Distillation Modeling

Note: For samples of pretreated wastewater, 1-percent sulfuric acid will be added as a component.

\begin{tabular}{|c|c|c|c|}
\hline Urine Wastewater & $\begin{array}{c}\text { Pre-Mixed } \\
\text { Concentration } \\
{[\mathrm{mg} / \mathrm{L}]}\end{array}$ & $\begin{array}{c}\text { Mixed with } \\
\text { Humidity } \\
\text { Condensate } \\
\text { Water } \\
\text { [mg/L] }\end{array}$ & $\begin{array}{c}\text { Target } \\
\text { Concentration } \\
{[\mathrm{mg} / \mathrm{L}]}\end{array}$ \\
\hline Formic acid & 64 & 31.57 & 0.017 \\
\hline Oxalic acid & 27 & 15.12 & 0.0079 \\
\hline Citric acid & 79.3 & 345 & 0.00018 \\
\hline Lactic acid & 369 & 159 & 0.084 \\
\hline Uric acid & 471 & 203 & 0.11 \\
\hline Taurine & 523 & 225 & 0.12 \\
\hline Histidine & 1169 & 50.3 & 0.026 \\
\hline L-glutamic acid & 412 & 177 & 0.093 \\
\hline Hippuric acid & 1711 & 736 & 0.039 \\
\hline Phenol & 292 & 126 & 0.117 \\
\hline$\alpha$-D-glucose & 7930 & 3410 & 0.32 \\
\hline Creatinine & 1787 & 768 & 0.077 \\
\hline Methanol & 5.1 & 4.45 & 0.0042 \\
\hline Ethanol & 1.5 & 5.58 & 0.0052 \\
\hline Urea & 13400 & 5760 & 0.0576 \\
\hline Sodium chloride & 1449 & 630 & 5.8 \\
\hline Potassium sulfate & 2632 & 1145 & 11 \\
\hline Potassium chloride & 1641 & 714 & 6.6 \\
\hline Magnesium chloride & 431 & 187 & 1.7 \\
\hline Calcium chloride & 498 & 217 & 2.0 \\
\hline Potassium & & & \\
\hline bicarbonate & 611 & 266 & 2.5 \\
\hline Sodium sulfate & 3068 & 1335 & 12 \\
\hline Sodium bicarbonate & 697 & 303.2 & 2.8 \\
\hline Sulfuric acid & & 10700 & 0 \\
\hline Sodium phosphate & 468 & 20 & 1.9 \\
\hline Ammonia & 468 & 20 & 0.5 \\
\hline
\end{tabular}




\section{Distillation}

\subsection{Energetic Requirements for Distillation}

\subsubsection{Pinch Technology Analysis}

Pinch technology represents a methodology for minimizing the energy costs in processes. In a given process, such as a distillation, the heating and cooling requirements can be described through a cold composite curve and a hot composite curve. An example of a hot composite curve is shown in Figure 1. Figure 1(a) shows two separate parts of a process. In the first part of the process, a stream is cooled from $180{ }^{\circ} \mathrm{C}$ to $80{ }^{\circ} \mathrm{C}$ with a heat capacity of 20 kilowatts per degrees Celsius $\left(\mathrm{kW} /{ }^{\circ} \mathrm{C}\right)$. In the second part, a stream is cooled from $130{ }^{\circ} \mathrm{C}$ to $40{ }^{\circ} \mathrm{C}$ with a heat capacity of $40 \mathrm{~kW} /{ }^{\circ} \mathrm{C}$. The x-axis is the enthalpy change for the process. The y-axis is the temperature change of the stream. In Figure 1(b), the composite curve represents the total system, not just the individual streams. In this composite curve, there are no points were one temperature corresponds to more than one enthalpy change. Where the two streams overlap in temperature in Figure 1(a), the heat capacity for the overlapping temperatures of the two streams is presented as the sum of the heat capacities of the two separate streams (in this case, $60 \mathrm{~kW} /{ }^{\circ} \mathrm{C}$ ) in the composite curve [see Figure 1(b)].

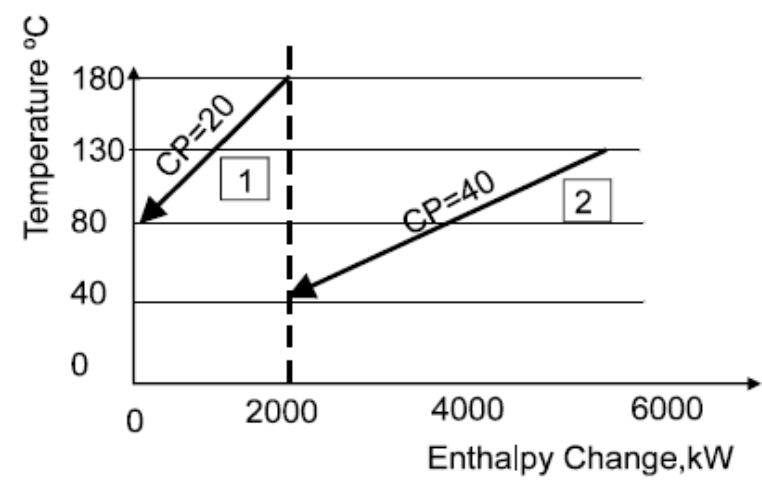

(a)

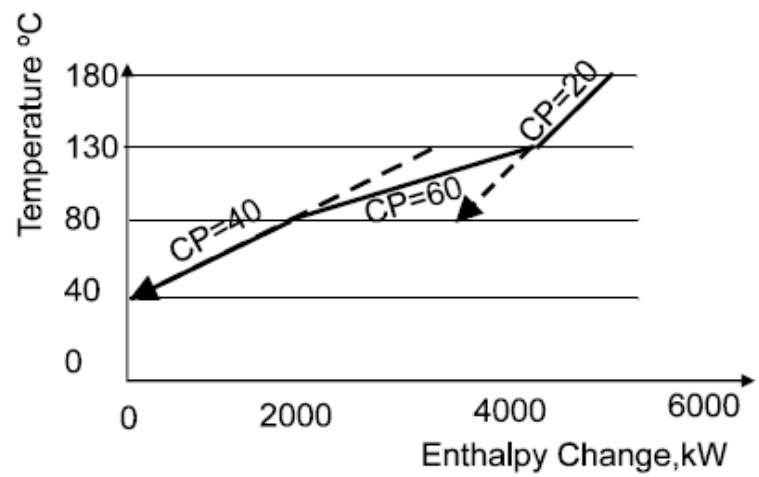

(b)

Figure 1: Composite Curves of a Cooling Requirement in a Process

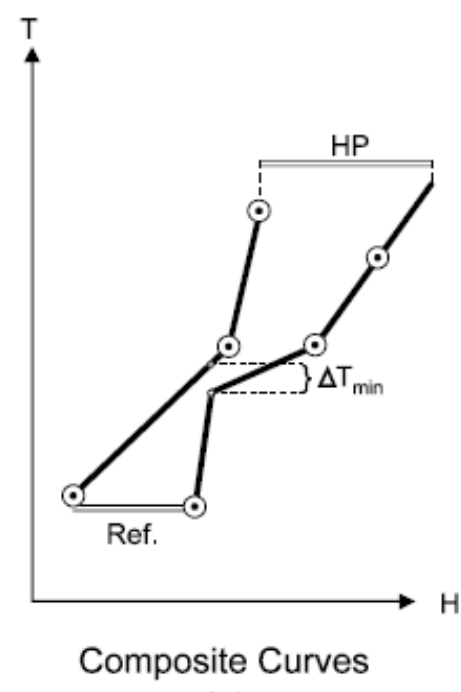

(a)

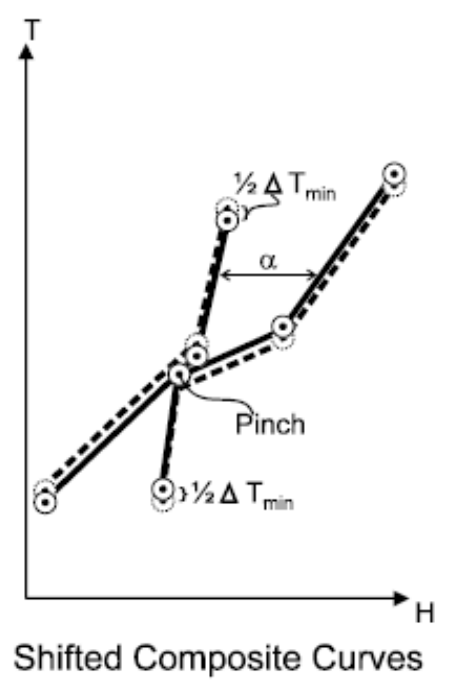

(b)

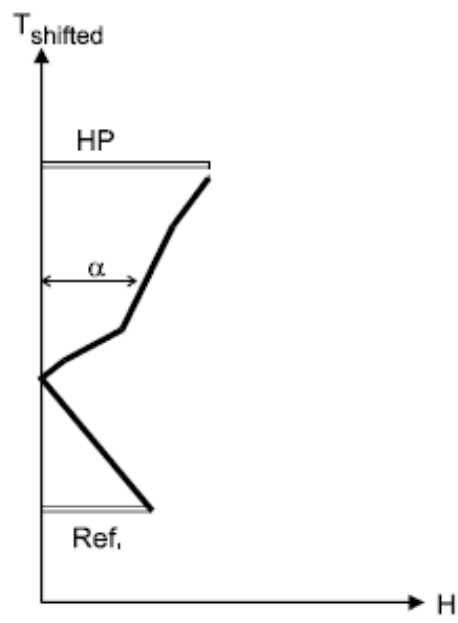

Grand Composite Curves

(c) 
Figure 2: Construction of the Grand Composite Curve (GCC)

Figure 2a, shows the cold composite (the curve to the right of the other) and the hot composite curve. In order to make the grand composite curve (GCC), which is used in this section to optimize the heat management in the column in this section of the report, the temperature of the cold composite curve is raised by half of the minimum temperature difference of the two curves. The temperature of the hot composite curve is lowered by half of this same temperature difference. The result of this operation is shown in Figure 2b. The GCC is reached when the y-axis is shifted such that within the operating temperature of the process, the enthalpy difference between the cold composite curve and the hot composite curve at a given temperature is equal to the GCC. $\Delta \mathrm{T}_{\min }$ is the minimum difference in temperature between the two composite curves (Figure 2a). The "ideal" profile described in the following column targeting analysis describes the situation where a pinch is made and $\Delta \mathrm{T}_{\min }$ is equal to zero [5].

\subsection{Column Targeting Analysis}

\subsubsection{Pinch Technology Analysis}

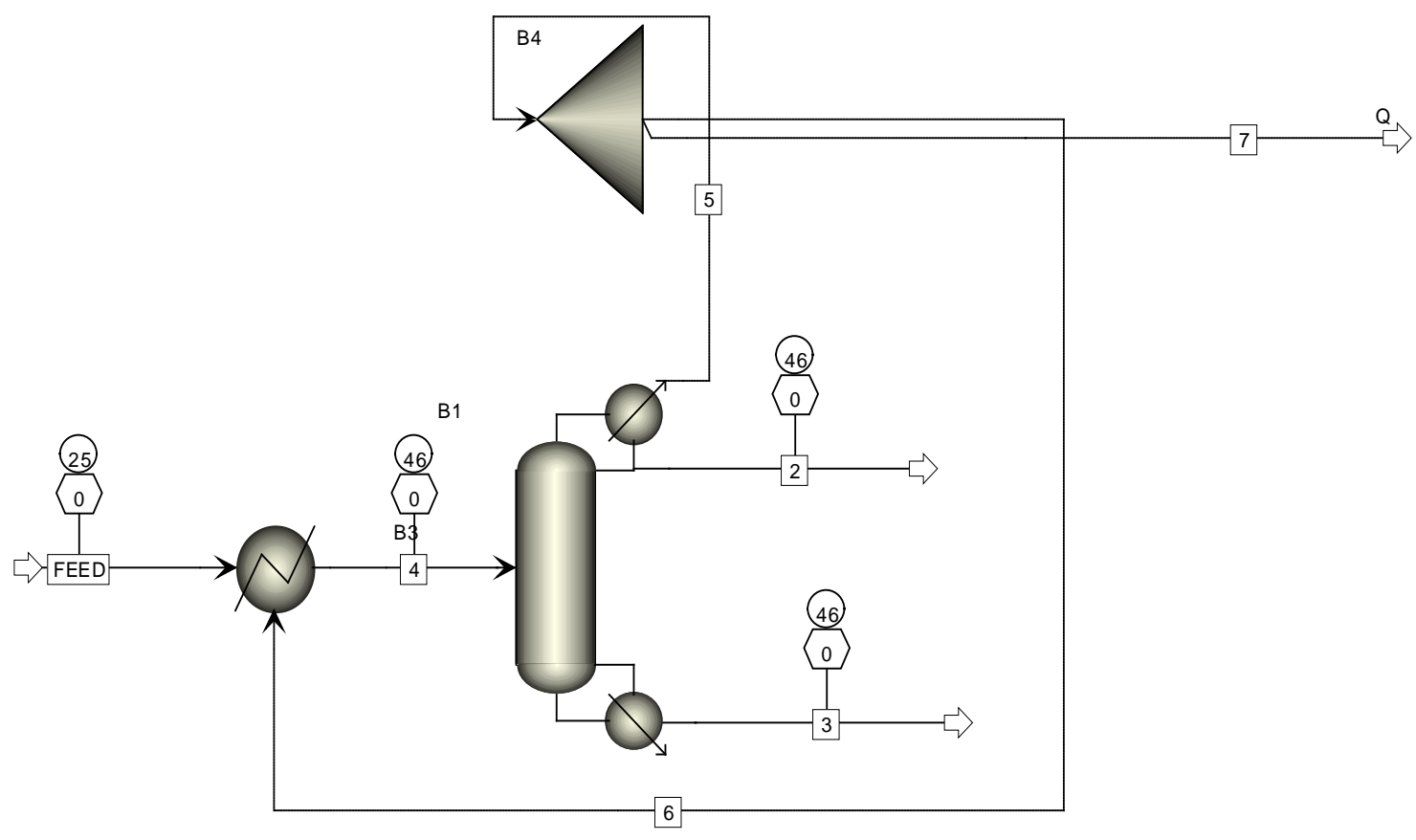

\section{Figure 3: Scheme 1 - Aspen Plus ${ }^{\circledR}$ Model for Placement of the Feed}

A model in Aspen Plus ${ }^{\circledR}$ was developed to determine the energy requirements for the distillation of water with a few basic components (see Figure 3). The components used in this model are sodium chloride (0.01), methanol $\left(4.45 \times 10^{-6}\right)$, acetic acid $\left(8.18 \times 10^{-6}\right)$, and sulfuric acid $(0.00107)$. The mass fractions of the components input are indicated in brackets. Fifty-five percent of the heat from the condenser is used to heat the feed stream to the distillation column. The flow rate of the feed is $20 \mathrm{~kg} / \mathrm{day}$.

The height equivalent theoretical plate (HETP) for 6.35-millimeter (mm) Raschig rings is about 0.3 feet (ft). The diameter of the column is calculated by Aspen Plus ${ }^{\circledR}$ to be 6.3 centimeters $(\mathrm{cm})[6]$. A ten-stage column would then be $3 \mathrm{ft}$. 


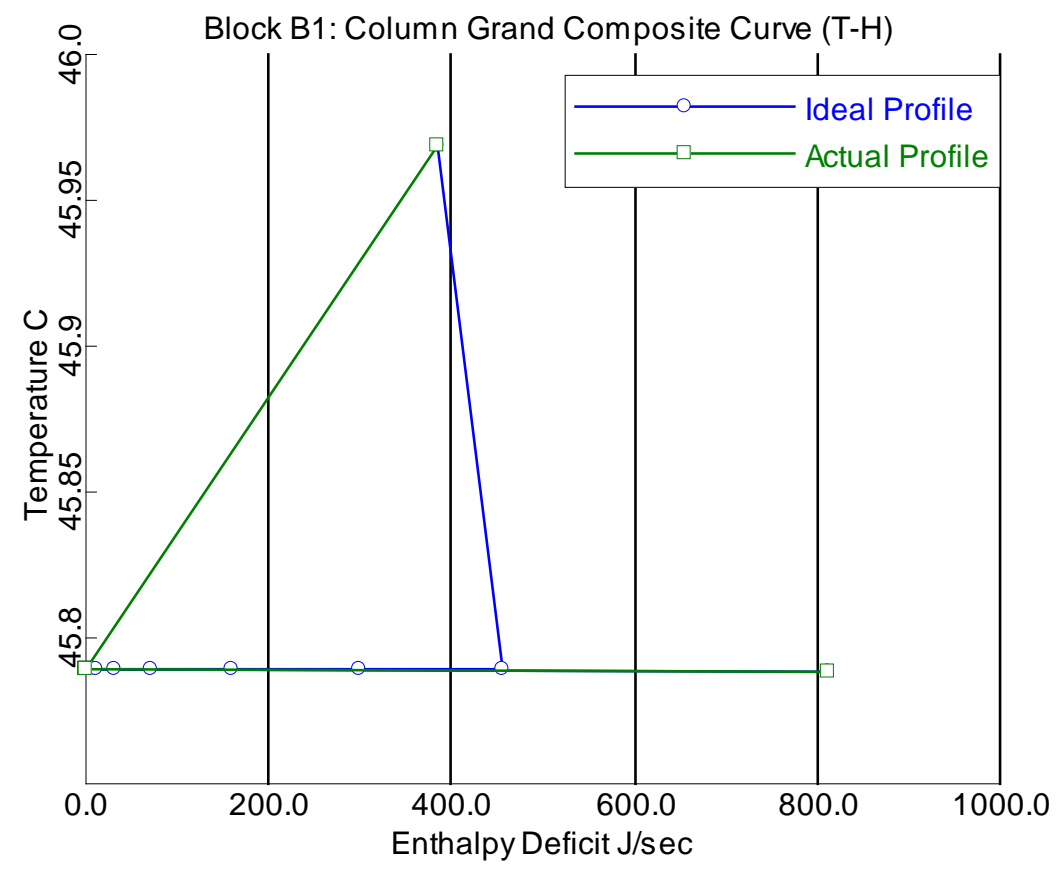

Figure 4: Feed Set at Stage 1

Note: Reflux Ratio $=1$. Condensor duty $=-814.1$ watts $(\mathrm{W})$. Reboiler Duty $=386.2 \mathrm{~W}$.

\subsubsection{Location of the Feed}

Figure 4 through Figure 14 depict the column grand composite curves (CGCC) of the distillation column described in this section. The goal of this part of the study was to determine the optimum feed position with respect to the thermal analysis of the column. From the CGCC (T-H) plots drawn in the applicable figures, it can be seen that the positioning of the feed anywhere from stage 1 (the top of the column) to stage 8 (Figures 4 to 11) is non-ideal. The actual profile and the ideal profile are closest to each other when the feed stage is set to stage 10 (at the reboiler). As demonstrated in Figures 12 and 13 where the feed stage is added at stage 9, the position of the feed can be changed above stage 10 and the CGCC plots can describe the profile as closer to ideal when a heat duty is added one stage at the stage where the feed stream is connected (see Figure 13). The total duty of the additional heat stream and the reboiler is higher than the duty on the reboiler in Figure 14. The column construction depicted by Figure 14 is therefore used in the analysis of purity levels obtainable through a 10-stage separation with a distillation column for wastewater components. 


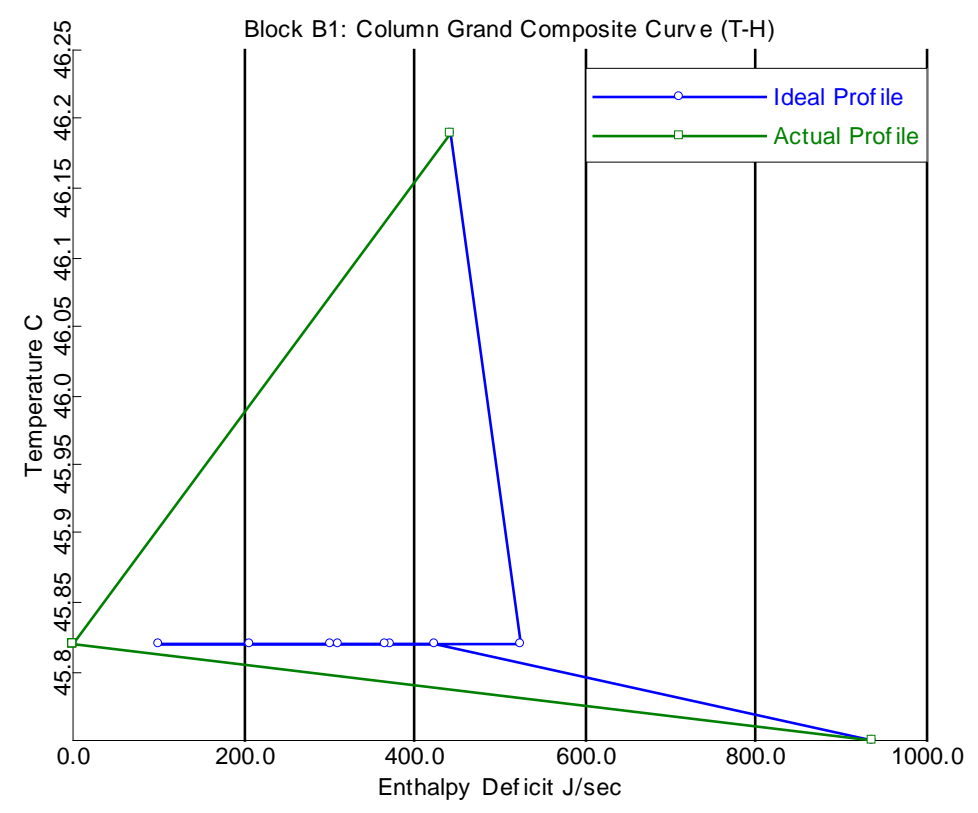

Figure 5: Feed Set at Stage 2

Note: Reflux ratio $=1$. Condensor duty $=-938.5 \mathrm{~W}$. Reboiler duty $=442.2 \mathrm{~W}$.

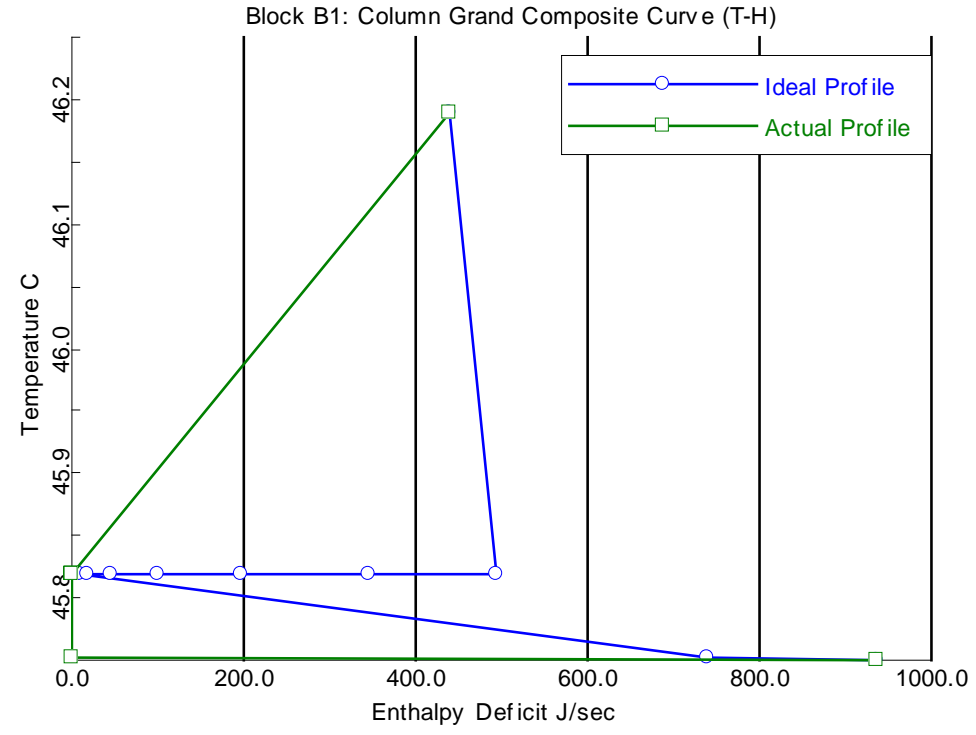

Figure 6: Feed Set at Stage 3

Note: Reflux Ratio $=1$. Condensor duty $=-937.9 \mathrm{~W}$. Reboiler duty $=441.9 \mathrm{~W}$. 


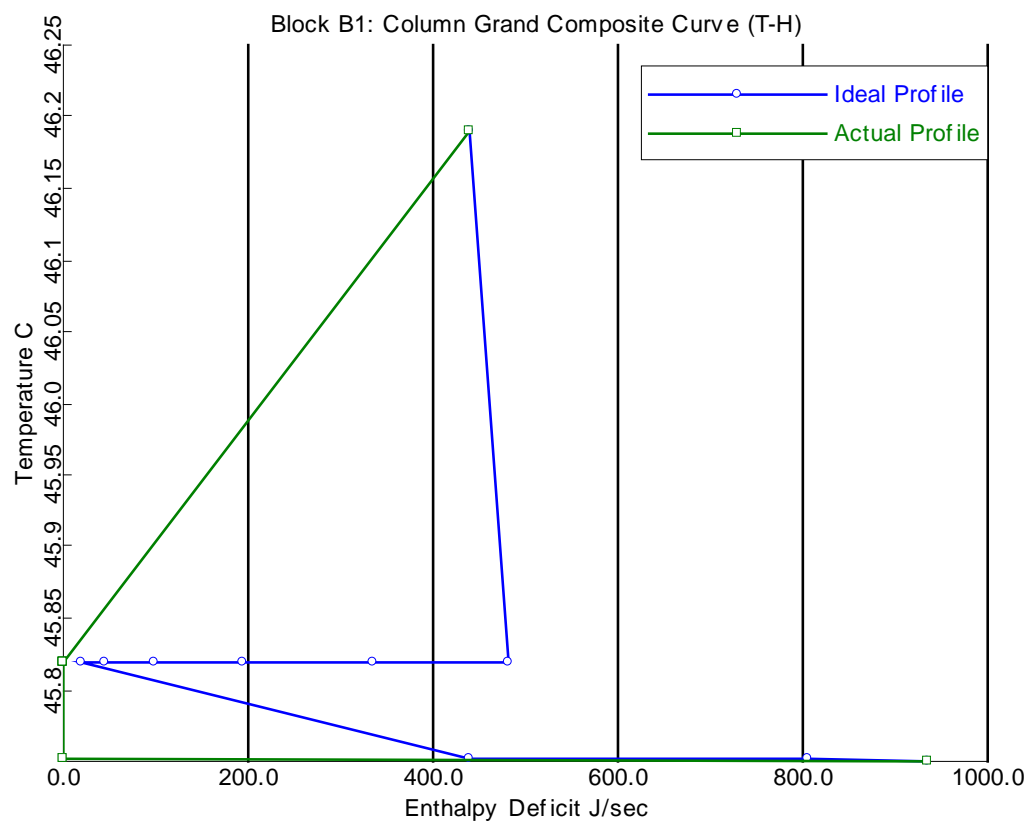

Figure 7: Feed Set at Stage 4

Note: Reflux ratio $=1$. Condensor duty $=-937.9 \mathrm{~W}$. Reboiler duty $=441.9 \mathrm{~W}$.

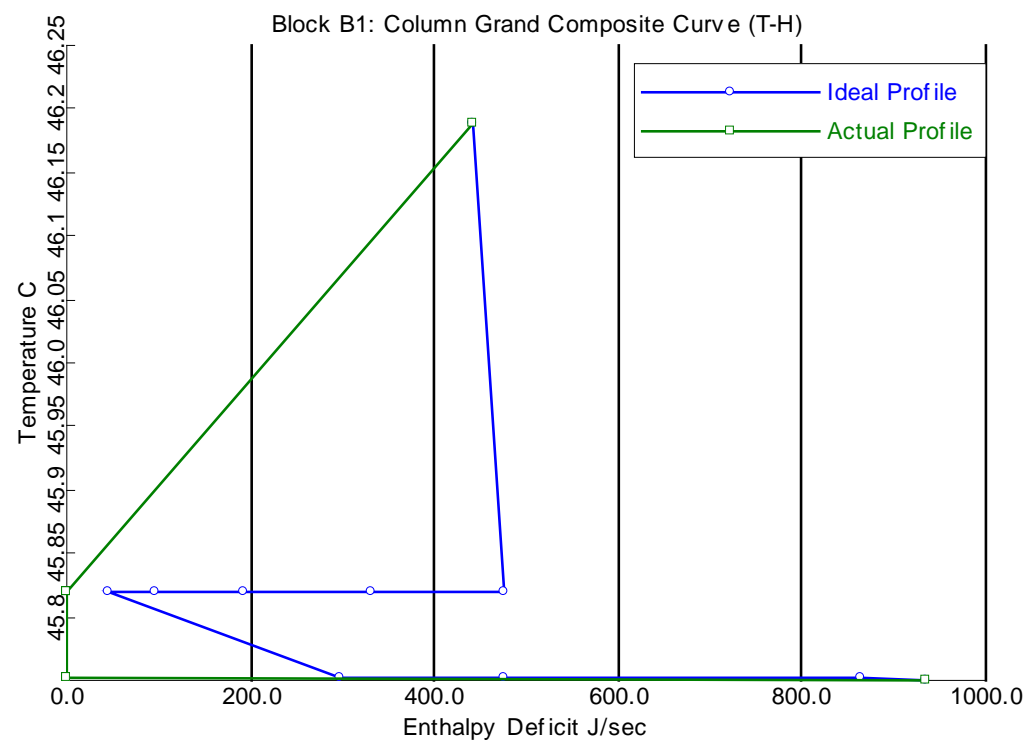

Figure 8: Feed Set at Stage 5

Note: Reflux ratio $=1$. Condensor duty $=-937.9 \mathrm{~W}$. Reboiler duty $=441.9 \mathrm{~W}$. 


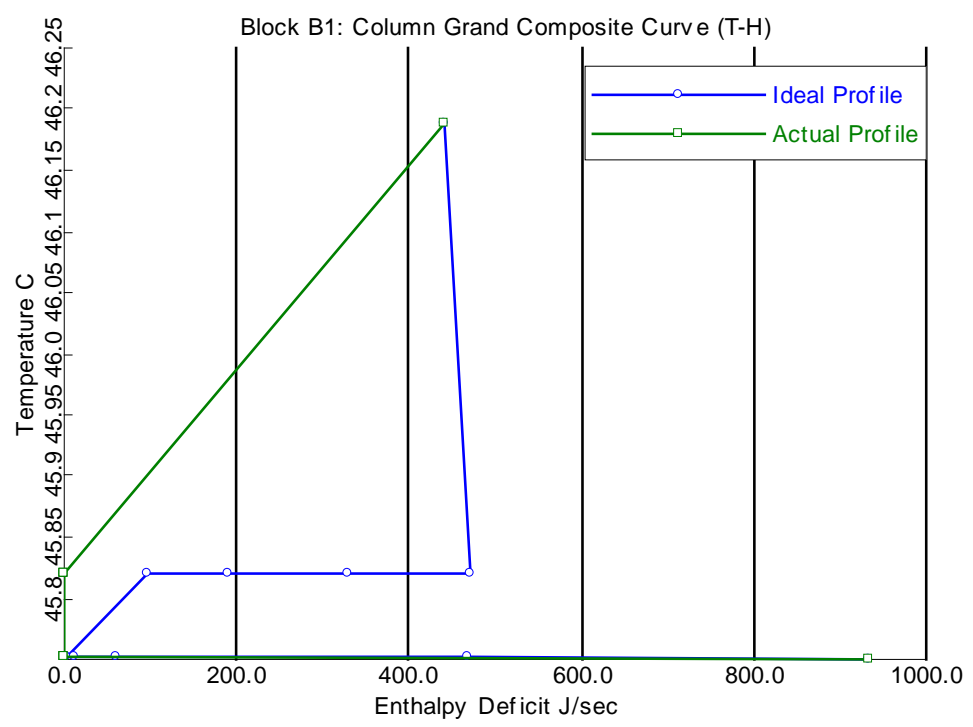

Figure 9: Feed Set at Stage 6

Note: Reflux ratio $=1$. Condensor duty $=-937.9 \mathrm{~W}$. Reboiler duty $=441.9 \mathrm{~W}$.

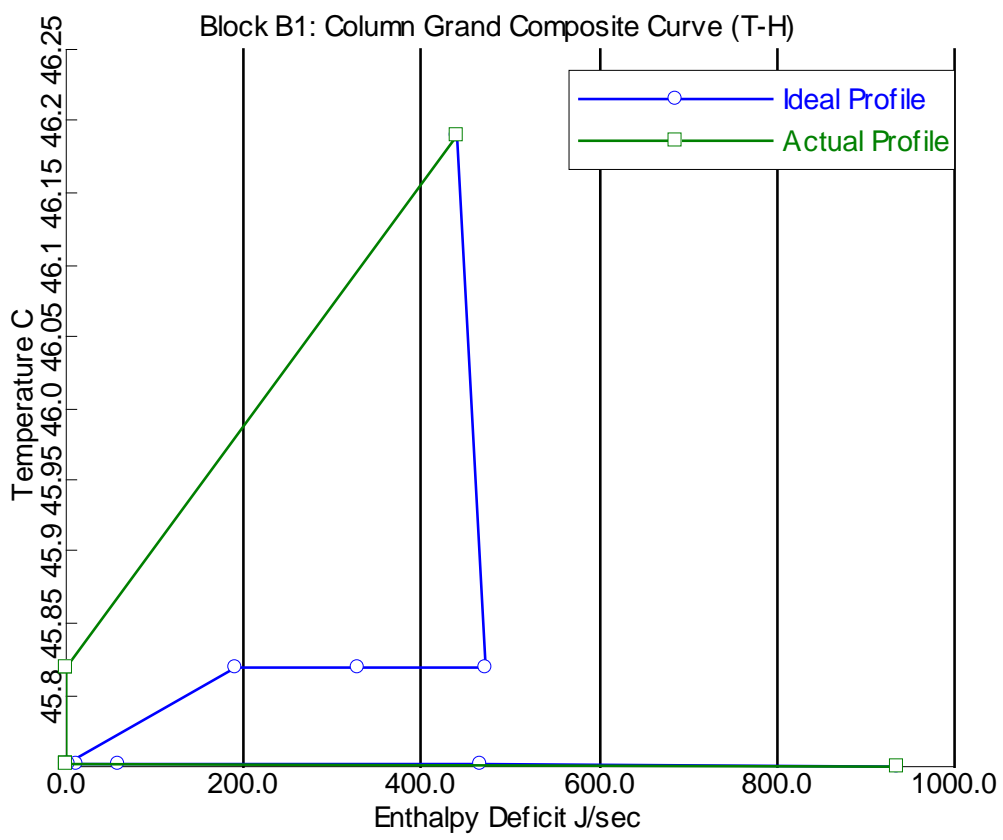

Figure 10: Feed Set at Stage 7

Note: Reflux ratio $=1$. Condensor duty $=-937.9 \mathrm{~W}$. Reboiler duty $=441.9 \mathrm{~W}$. 


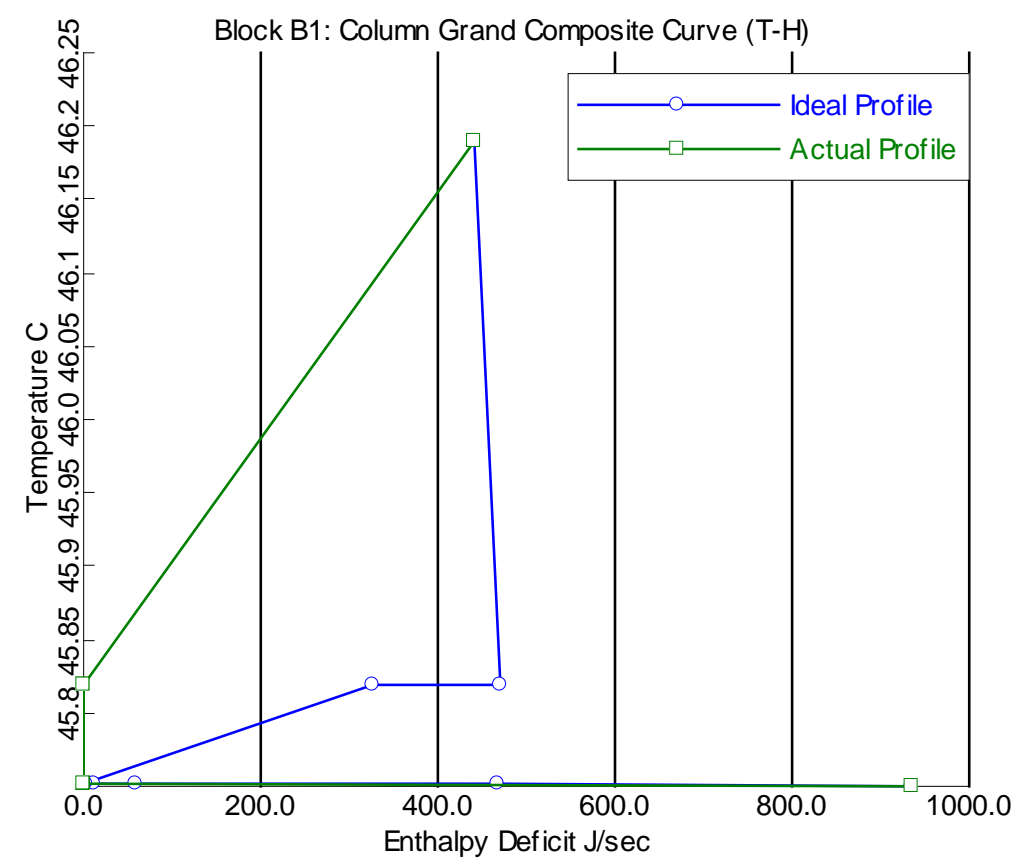

Figure 11: Feed Set at Stage 8

Note: Reflux ratio $=1$. Condensor duty $=-937.9 \mathrm{~W}$. Reboiler Duty $=441.9 \mathrm{~W}$ ( 55 percent of heat recycled from condenser to feed stream).

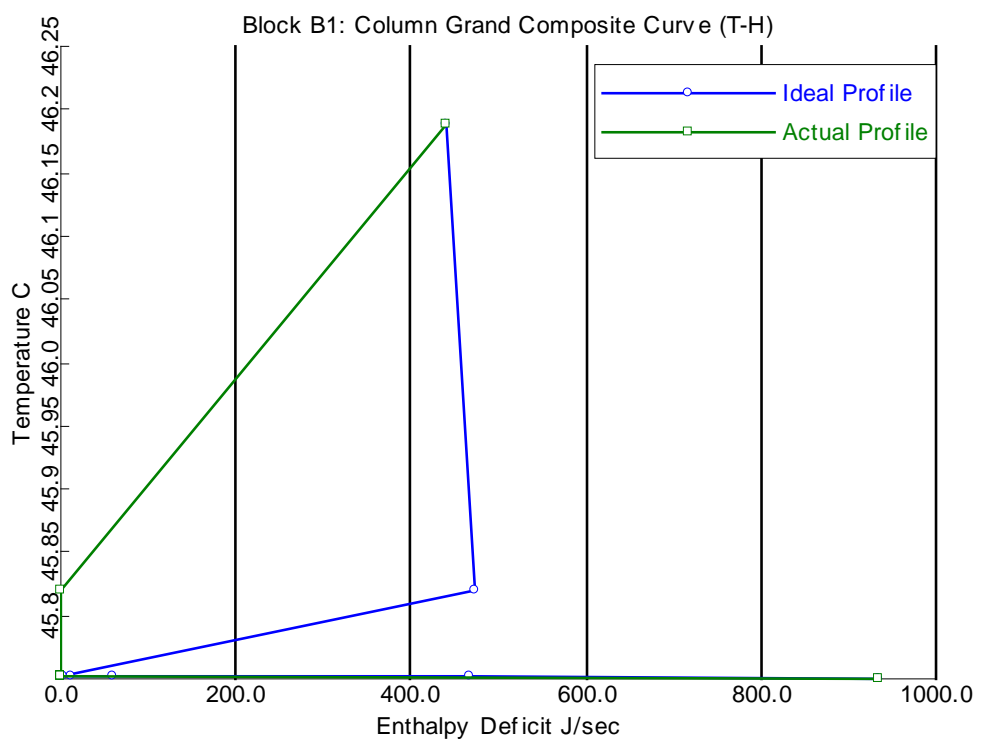

Figure 12: Feed Set at Stage 9

Note: Reflux ratio $=1$. Condensor duty $=-937.9 \mathrm{~W}$. Reboiler duty $=441.9 \mathrm{~W}$ (55 percent of heat recycled from condenser to feed stream). 


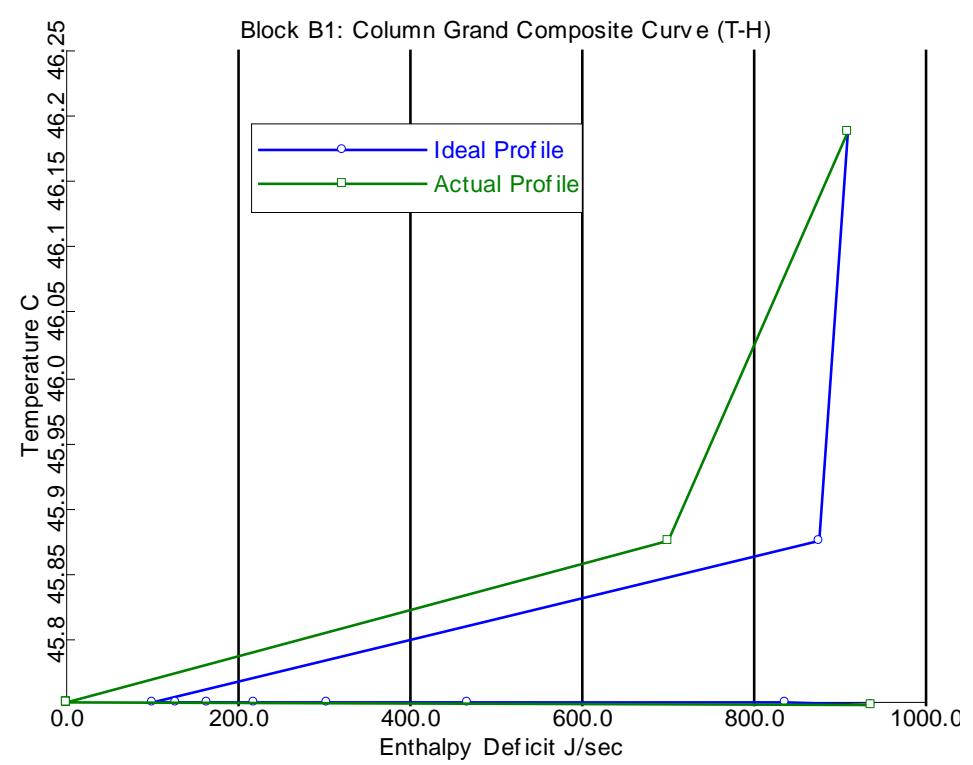

\section{Figure 13: Feed Set at Stage 9}

Note: Reflux Ratio $=1$. Condensor duty $=-937.9 \mathrm{~W}$. Reboiler duty $=210.9 \mathrm{~W}$ (5 percent of heat recycled from condenser to feed stream). An additional duty of $700 \mathrm{~W}$ is added to stage 9.

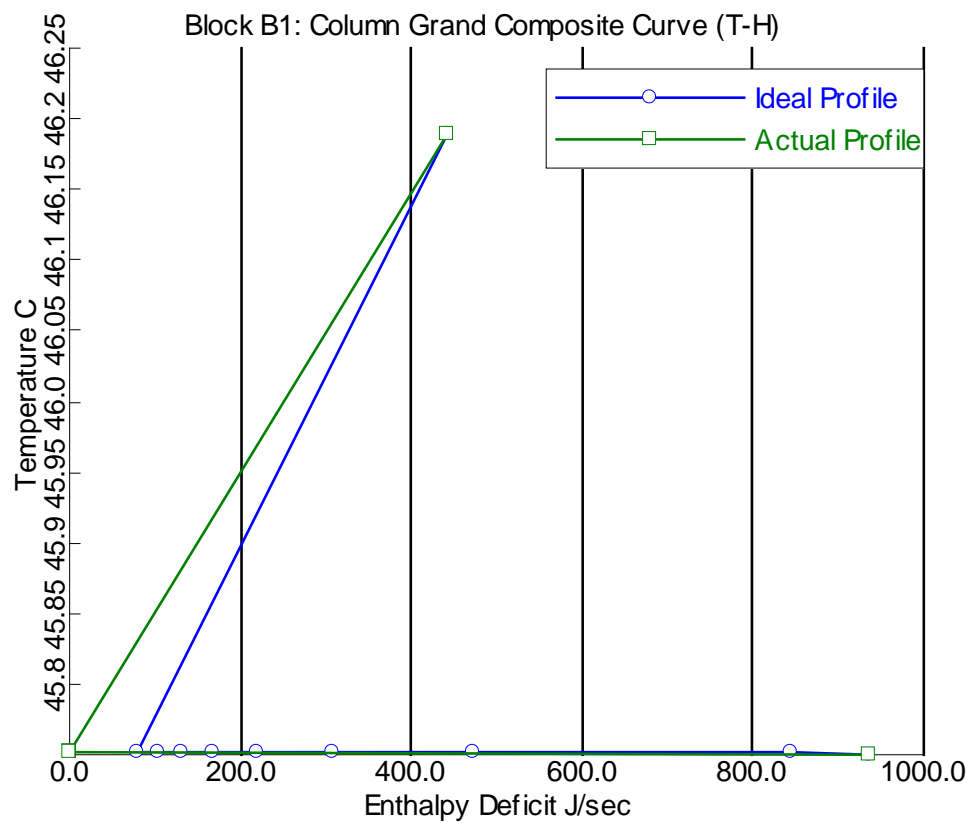

\section{Figure 14: Feed Set at Stage 10}

Note: Reflux ratio $=1$. Condensor duty $=-937.9 \mathrm{~W}$. Reboiler duty $=441.9 \mathrm{~W}(55$ percent of heat recycled from condenser to feed stream). 


\subsubsection{Varying the Reflux Ratio}

Changing the reflux ratio has an impact on both the extent to the separation of the components and the heat duty of the reboiler and condenser. Generally, the higher the reflux ratio the greater the separation and the more power is consumed in the separation process. Through the CGCC analysis in Figure 15 and Figure 16 , it can be determined that the reflux ratio set to 1 gives the most ideal profile for the curves.

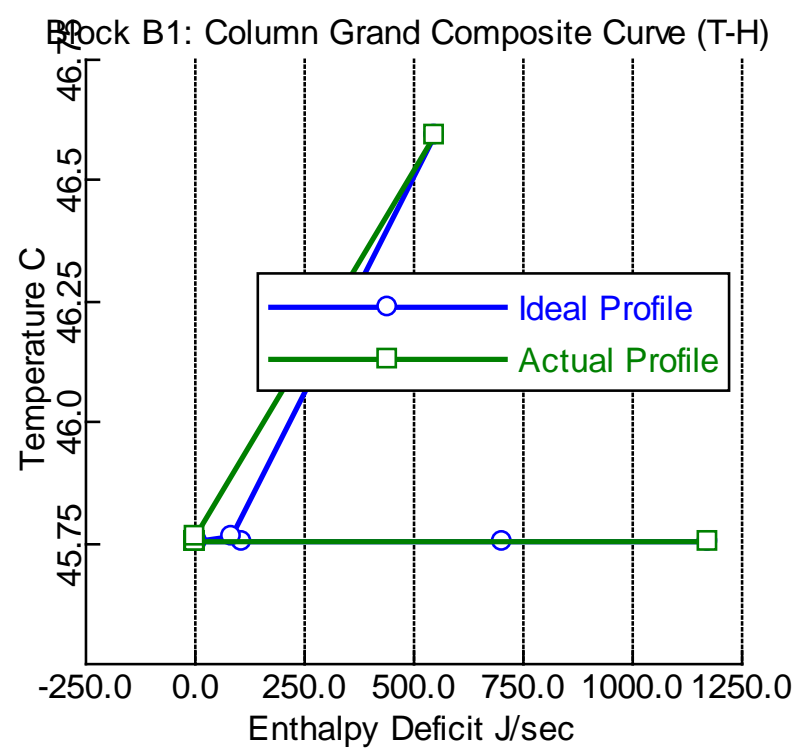

Figure 15: Feed at Stage 10

Note: When the reflux ratio is raised to 1.5, the column has a less ideal profile. Condenser duty $=-1172.4$ W. Reboiler Duty $=547.4 \mathrm{~W}$. 


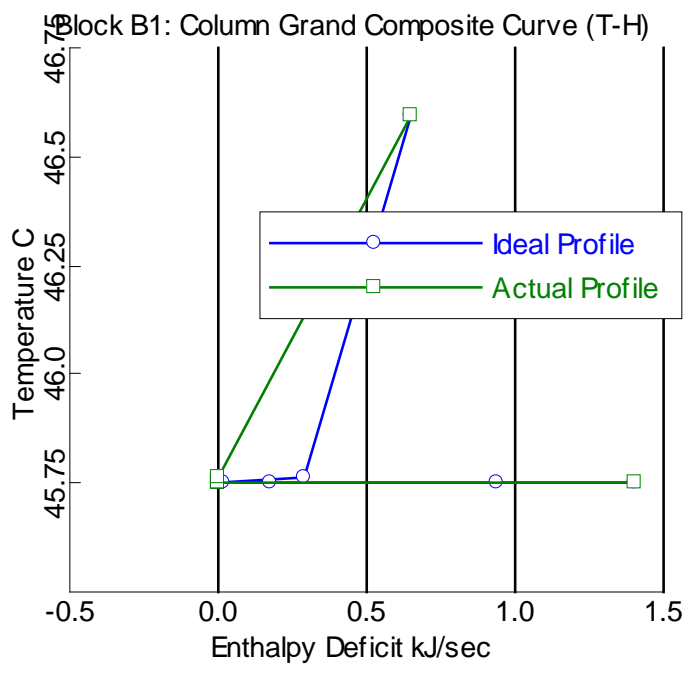

Figure 16: Feed at Stage 10

Note: When the reflux ratio is raised to 2.0, the column has a less ideal profile. Condenser duty = 1406.8566 W. Reboiler duty $=652.960977 \mathrm{~W}$.

\subsection{Humidity Condensate Distillation Model}

The Rafrac ${ }^{\circledR}$ column for HCA was run as a simulation with a reflux ratio of 1.0, a flow rate of 20 liters per day (L/day), and the feed inlet set to stage 10 of 10 . The distillate-to-feed ratio was set at 0.85 . The column pressure was set at 0.1 Bar. Fifteen-mm Raschig rings were selected as the packing material for the column. The HETP for this material is approximately $0.3 \mathrm{ft}$ (from vendor). For a 10-stage column, where the starting stage of the packing was set at 2 and the final stage of packing was 9 , the column diameter was calculated to be $6.4 \mathrm{~cm}$. The average pressure drop/height was calculated to be $0.0071 \mathrm{bar} / \mathrm{meter}(\mathrm{m})(0.87$ inches of water per foot (ft)) (for a flow rate of $20 \mathrm{~kg} / \mathrm{day}$ ).

The results of the separation through this column were analyzed to determine which components could be separated to their target concentrations in the distillate. For easier interpretation of the results, the components are analyzed in small groups of components. In the first group of components (see Table C), three components were not purified to their target values after 10 stages. These components are 2propanol, acetic acid, and ethylene glycol. These components are written in red in Table C. Acetic acid is particularly difficult to remove because there is a tangent pinch on the water end in the $x-y$ diagram of water and acetic acid (see Figure 17). The most common approach to separate acetic acid (if distillation is chosen to be the method) is to use an entrainer or solvent in an azeotropic distillation column to purify water contaminated with acetic acid. Another approach is to use a reactive distillation column [7].

Table C: Mass Fractions for Six Components in the Humidity Condensate Portion of Mixed Wastewater Stream

Note: Distillation with ten stages.

Component Mass Fraction

[Feed] [Distillate] [Target]

Mass Fraction 


\begin{tabular}{|lccl|}
\hline & & & \\
2-propanol & $2.59 \times 10^{-5}$ & $3.02 \times 10^{-5}$ & $2.4 \times 10^{-8}$ \\
Acetic Acid & $8.18 \times 10^{-6}$ & $4.58 \times 10^{-6}$ & $4.3 \times 10^{-9}$ \\
Ethylene Glycol & $5.73 \times 10^{-6}$ & $6.46 \times 10^{-6}$ & $5.3 \times 10^{-9}$ \\
Urea & $5.76 \times 10^{-3}$ & $3.33 \times 10^{-30}$ & $5.76 \times 10^{-8}$ \\
Acetyl Morpholine & $6.12 \times 10^{-7}$ & $1.15 \times 10^{-22}$ & $6.1 \times 10^{-9}$ \\
Caprolactam & $6.62 \times 10^{-6}$ & $6.28 \times 10^{-30}$ & $6.6 \times 10^{-9}$ \\
\hline
\end{tabular}

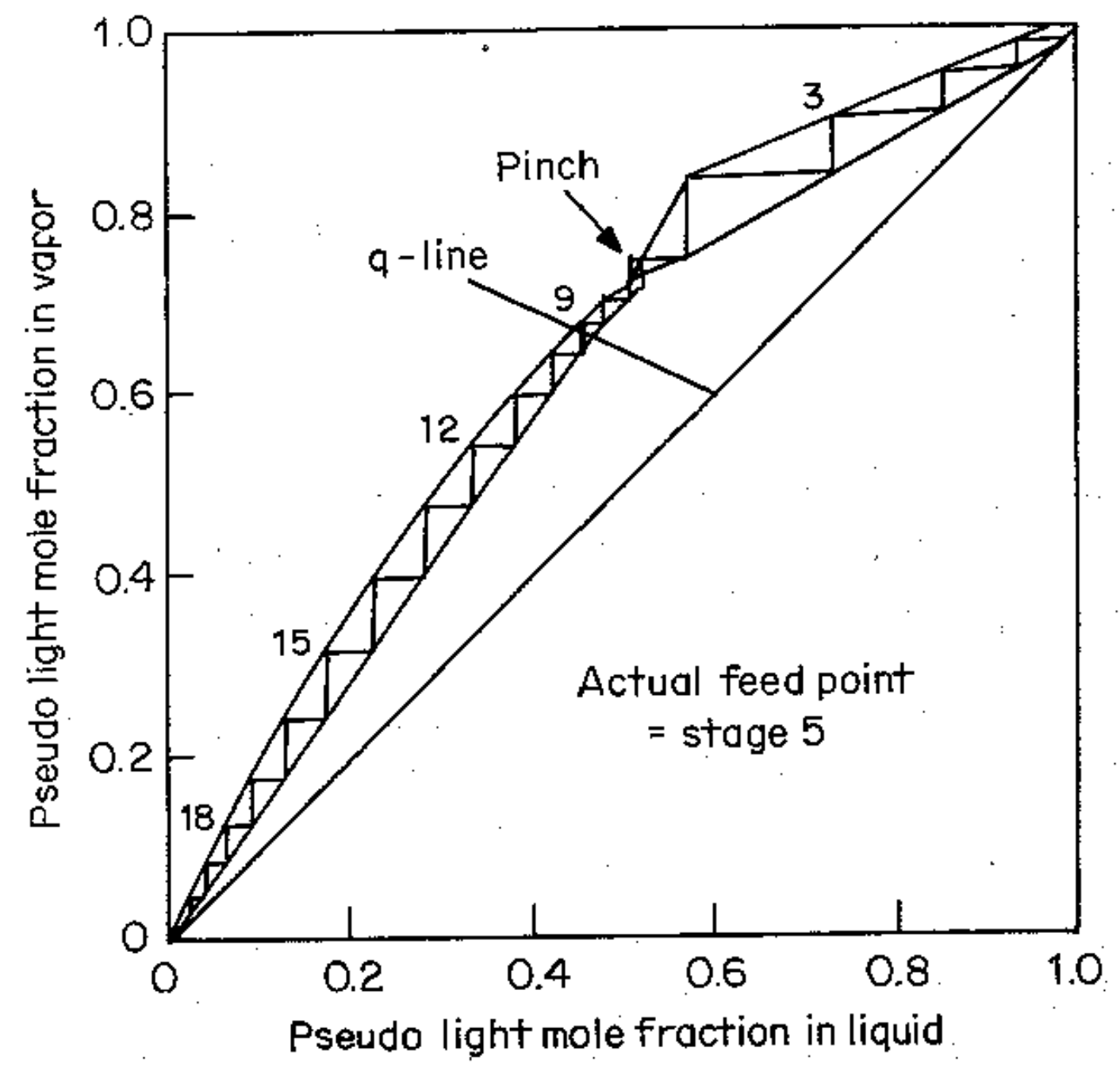

Figure 17: Example of a Pinch Point in an X-Y Diagram [8]

Urea is separated from water to the target purity in two stages. Acetyl morpholine is also separated after two stages. Propanediol is separated in three stages. Caprolactam is separated in two stages. See Figure 18 for a column profile plot indicating the concentrations of these components with respect to the stage number. 


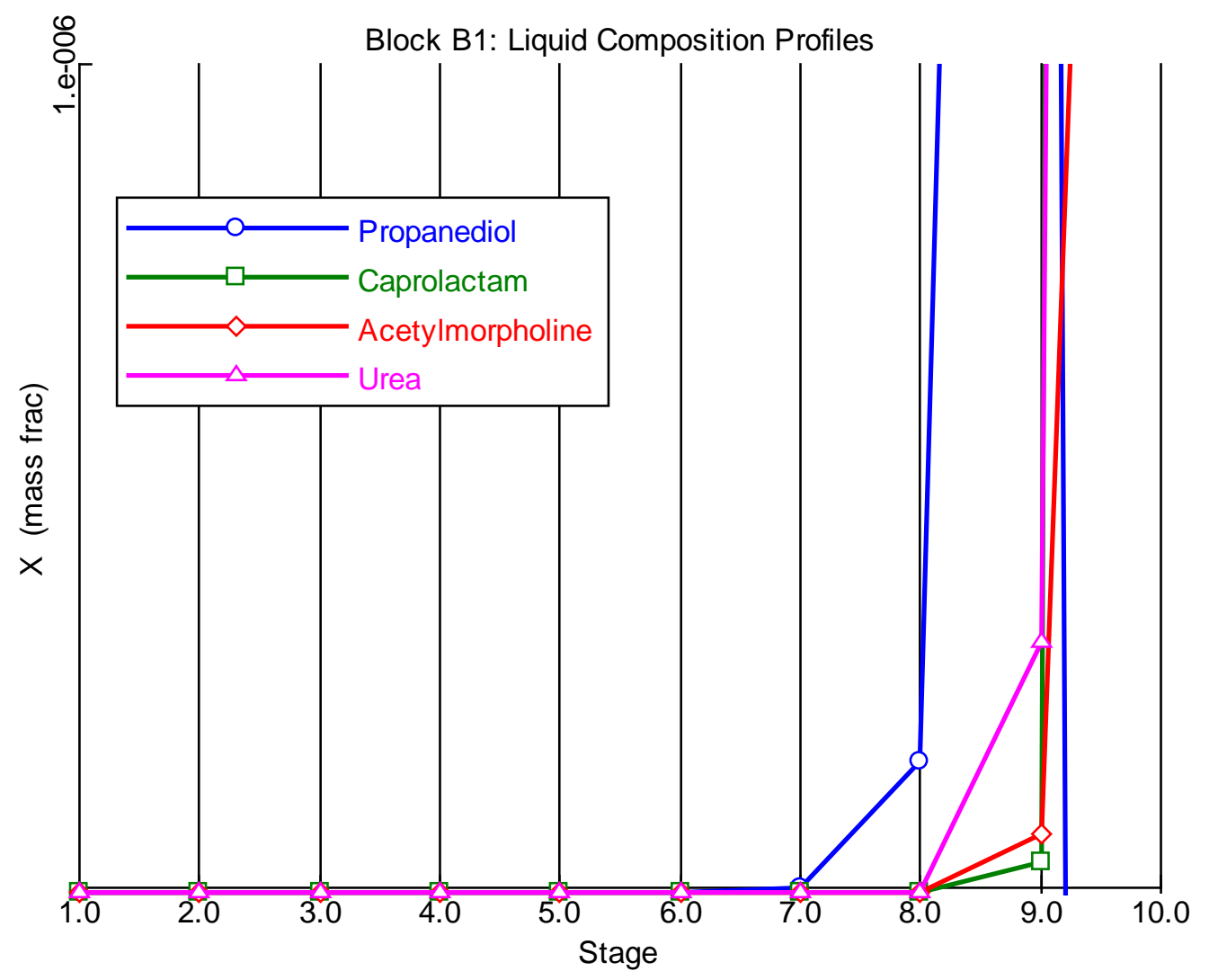

Figure 18: Column Profile Plot of Water Composition vs. Stage

The components that reach their target concentrations in Table D are propionic acid, butyric acid, isobutyric acid, ethyl hexanoate, and ethyl morpholine. See Figure 19 for a plot of stage number vs. component concentration. The remaining components in Table D cannot be separated through a 10-stage distillation, thus, they require a different procedure for removal. Tables $\mathrm{E}$ and $\mathrm{F}$ show the concentrations of the rest of the humidity condensate components. 
Table D: Mass Fractions for Eight Components in the Humidity Condensate Portion of Mixed Wastewater Stream

Note: Distillation with ten stages. Propionic acid is a borderline component; it is written in green. The components written in red cannot be separated in ten stages.

\section{Component Mass Fraction}

[Feed] [Distillate] [Target]

Mass Fraction

Glycolic Acid

Ethanol

Formaldehyde

Formic Acid

Methanol

Butoxyethanol

Butanol

Butyric Acid

Propionic Acid

Ethyl Hexanoate

Isobutyric Acid

Ethylmorpholine

$$
\begin{aligned}
& 5.71 \times 10^{-6} \quad 4.0 \times 10^{-6} \quad 3.0 \times 10^{-9} \\
& 5.58 \times 10^{-6} \quad 6.61 \times 10^{-6} \quad 5.2 \times 10^{-9} \\
& 4.56 \times 10^{-6} \quad 3.02 \times 10^{-5} \quad 4.6 \times 10^{-8} \\
& 3.16 \times 10^{-5} \quad 4.58 \times 10^{-6} \quad 1.7 \times 10^{-8} \\
& 4.45 \times 10^{-6} \quad 5.17 \times 10^{-6} \quad 4.2 \times 10^{-9} \\
& 6.33 \times 10^{-7} \quad 5.68 \times 10^{-7} \quad 5.9 \times 10^{-10} \\
& 5.25 \times 10^{-7} \quad 6.19 \times 10^{-7} \quad 4.9 \times 10^{-8} \\
& 2.1 \times 10^{-7} \quad 8.7 \times 10^{-11} \quad 1.1 \times 10^{-10} \\
& 2.19 \times 10^{-6} \quad 1.29 \times 10^{-10} \quad 1.2 \times 10^{-9} \\
& \begin{array}{lll}
2.0 \times 10^{-7} & 1.55 \times 10^{-29} & 2.1 \times 10^{-9}
\end{array} \\
& 1.8 \times 10^{-7} \quad 5.45 \times 10^{-12} \quad 9.4 \times 10^{-11} \\
& 2.5 \times 10^{-6} \quad 6.92 \times 10^{-9} \quad 1.4 \times 10^{-8}
\end{aligned}
$$

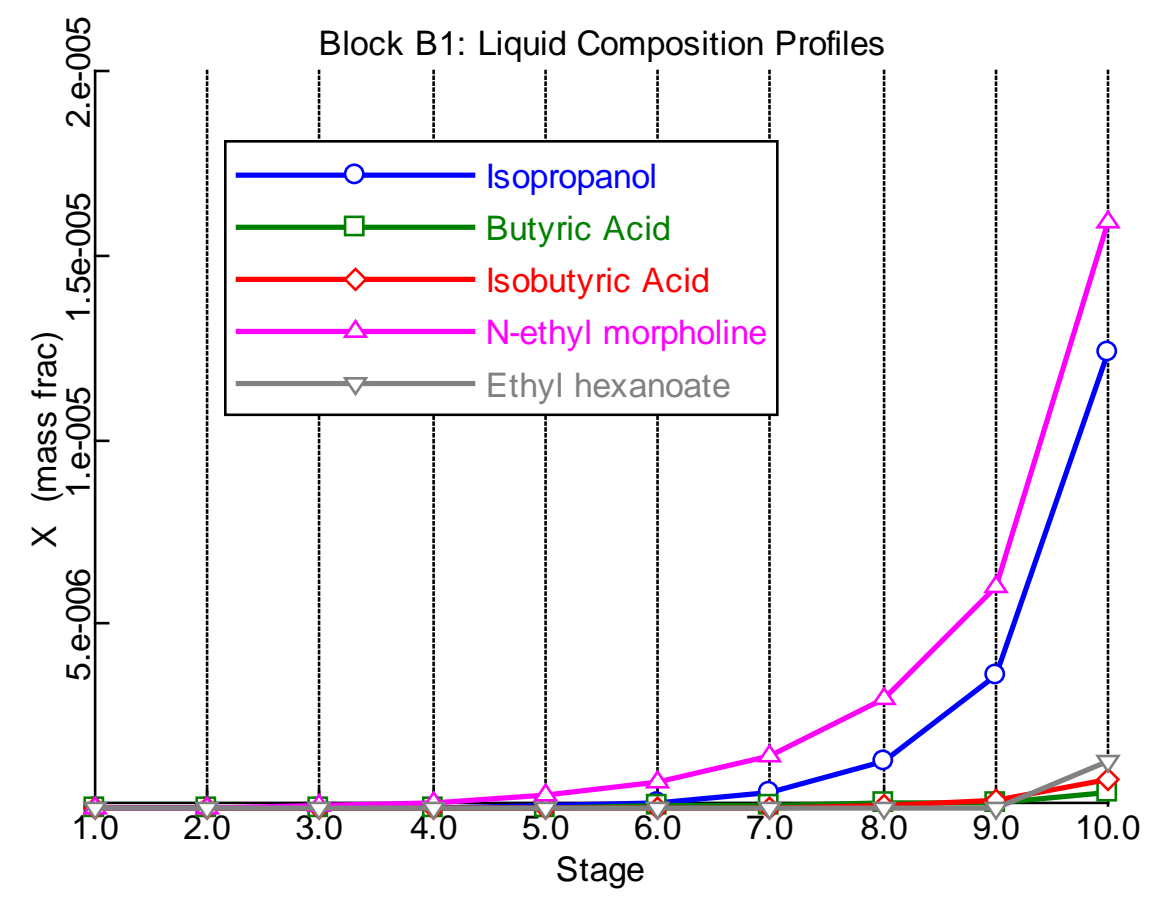

Figure 19: Separable Components

Note: Of the components that are separable, propionic acid separates after ten stages and butoxyethoxyethanol separates after six stages to the target concentration. 
Table E: Mass Fractions for Nine Components in the Humidity Condensate Portion of Mixed Wastewater Stream

Note: The components listed in red cannot be removed from water sufficiently in a ten-stage column. The component listed in green is considered to be a borderline component. The remaining components can be separated sufficiently in a ten-stage column.

\begin{tabular}{|c|c|c|}
\hline Component Mass Fr & raction & \\
\hline [Feed] & [Distillate] & [Target] \\
\hline Butoxyethanol & $5.74 \times 10^{-7}$ & $4.2 \times 10^{-10}$ \\
\hline Carbon Disulfide & $4.4 \times 10^{-7} \quad 5.15 \times 10^{-7}$ & $4.4 \times 10^{-9}$ \\
\hline Ethoxyethanol & $2.8 \times 10^{-7} \quad 2.98 \times 10^{-7} \quad 2$ & $2.6 \times 10^{-10}$ \\
\hline Dimethylformamid & de $3.4 \times 10^{-7}$ & $3.4 \times 10^{-9}$ \\
\hline Morpholine & $3.11 \times 10^{-8}$ & $2.2 \times 10^{-9}$ \\
\hline Hexanoic Acid & $3.57 \times 10^{-14}$ & $1.7 \times 10^{-10}$ \\
\hline Dibutylamine & $1.15 \times 10^{-12}$ & $3.2 \times 10^{-9}$ \\
\hline Diethyl Phthalate & $1.23 \times 10^{-29}$ & $6.0 \times 10^{-9}$ \\
\hline Pentanoic Acid & $2.06 \times 10^{-10}$ & $1.3 \times 10^{-10}$ \\
\hline
\end{tabular}

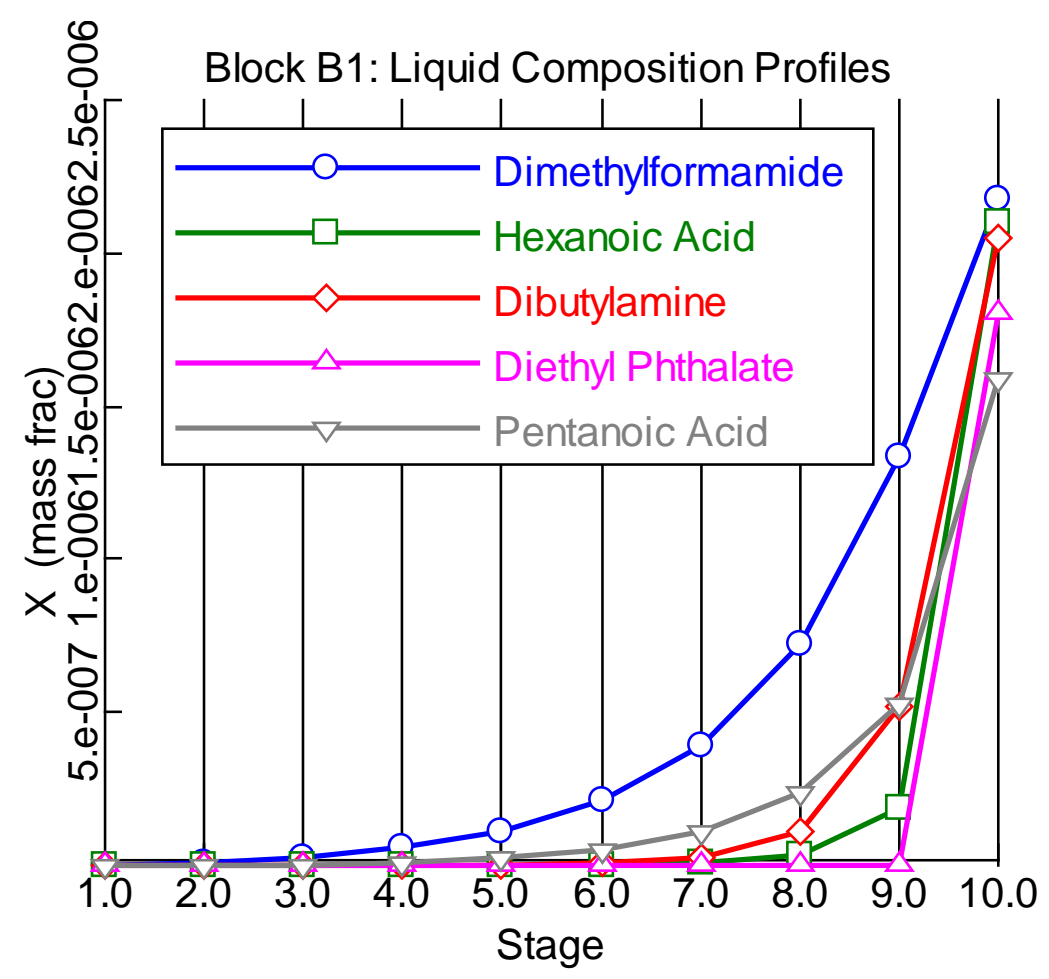

Figure 20: Liquid Composition Profiles of Components Separated Sufficiently in the Ten-stage Column

Note: Pentanoic acid and dimethylformamide are considered borderline cases.

Borderline component, dimethylformamide require a minimum of ten stages for sufficient separation. Hexanoic acid requires five stages. Dibutylamine requires five stages. Diethyl phthalate requires one stage for separation to an acceptable purity level of water (see Figure 20). 
Table F: Mass Fractions for Ten Components in the Humidity Condensate Portion of Mixed Wastewater Stream

Note: Components marked in red do not meet the criteria for separation. The remaining components are effectively separated by the ten-stage distillation column.

\section{Component Mass Fraction}

\section{[Feed] [Distillate] [Target]}

\begin{tabular}{llll} 
Acetone & $2.0 \times 10^{-7}$ & $2.28 \times 10^{-7}$ & \multicolumn{2}{c}{$2.0 \times 10^{-9}$} \\
Methyl Pyrrolidone & $3.4 \times 10^{-7}$ & $1.92 \times 10^{-26}$ & $1.9 \times 10^{-9}$ \\
Nonanoic Acid & $1.9 \times 10^{-7}$ & $8.78 \times 10^{-30}$ & $3.7 \times 10^{-9}$ \\
Lactic Acid & $3.2 \times 10^{-7}$ & $1.29 \times 10^{-28}$ & $8.4 \times 10^{-8}$ \\
Ethoxyethoxyethanol $3.54 \times 10^{-7}$ & $6.51 \times 10^{-21}$ & $1.8 \times 10^{-10}$ \\
Diacetone Alcohol & $7.0 \times 10^{-7}$ & $4.75 \times 10^{-13}$ & $7.0 \times 10^{-9}$
\end{tabular}

Methyl pyrrolidone requires two stages to achieve sufficient separation. Nonanoic acid requires one stage. Ethoxyethoxyethanol requires four stages. Diacetone alcohol requires three stages for adequate separation. See Figure 21.

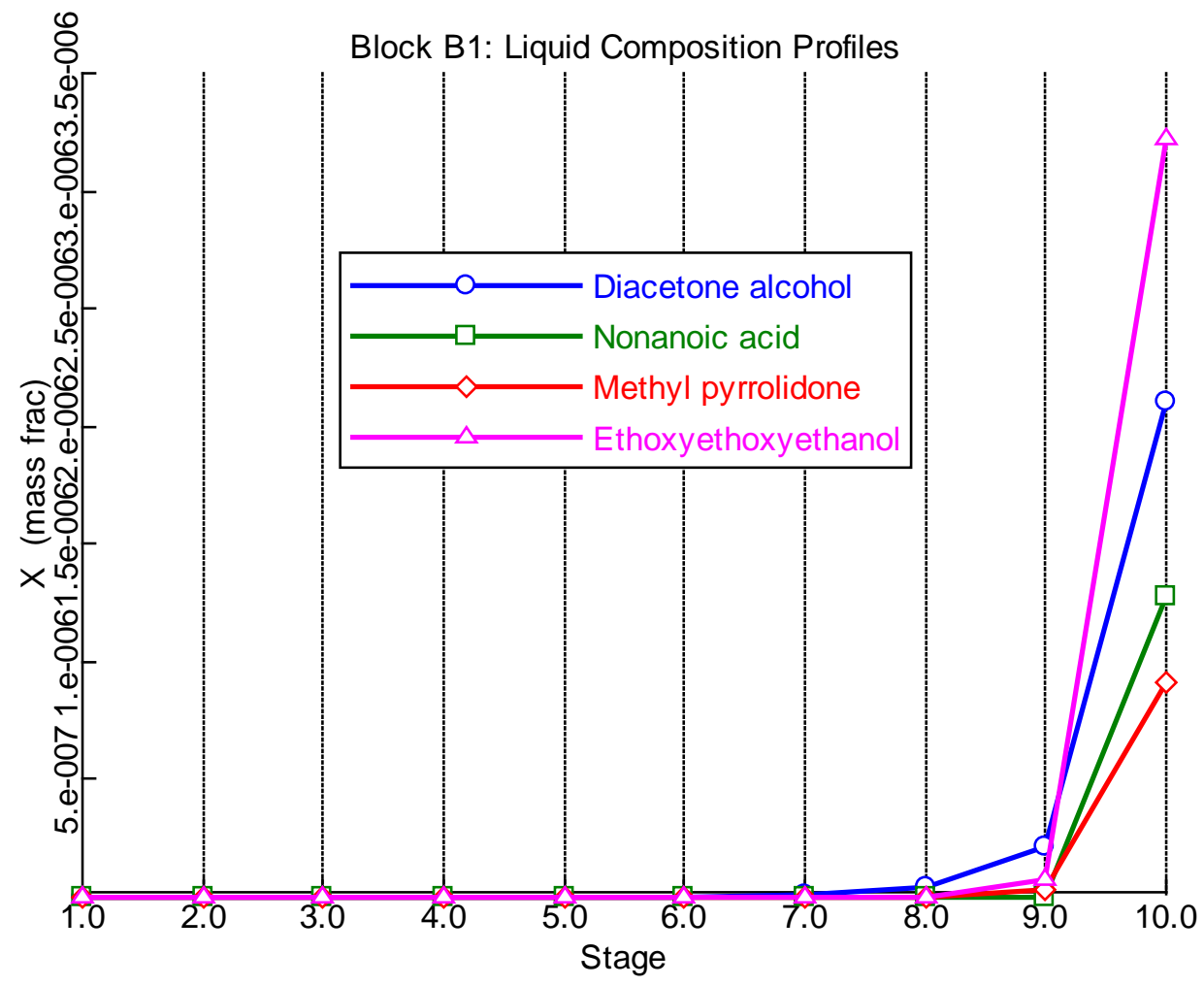

Figure 21: Stage Requirements for Separation of Four Components from Water

The components of the humidity condensate portion of the humidity condensate and urine wastewater stream, mixed as per the method described by the Exploration Life Support Water Recovery Test Plan (2009) [3], are denoted in Table G with their vapor pressures determined in the report, Development of Urine and Humidity Condensate Waste Water Feed Models for Water Recovery Processing Simulations [2]. 
The components that are effectively removed from water to NASA specifications are written in black. The remaining components are written in blue. These components require a different method to achieve an adequate removal from water. There are many potential methods for removing these components. Catalytic oxidation [9] and ion-exchange methods are two methods, which are currently in use aboard the International Space Station (ISS) for this purpose. Air stripping is later suggested in this report as a method for the removal of some of these components. 
Table G: Components and Vapor Pressures Calculated from PLXANT Data Input into Aspen Plus ${ }^{\circledR}$.

Note: The components not separated adequately are noted in blue.

\begin{tabular}{|c|c|c|c|c|}
\hline Name & \multicolumn{2}{|c|}{ Estimated Values (Pa) } & \multirow{2}{*}{\multicolumn{2}{|c|}{ 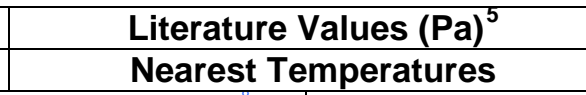 }} \\
\hline & $25^{\circ} \mathrm{C}$ & $40^{\circ} \mathrm{C}$ & & \\
\hline Formaldehyde & $5.64 \mathrm{E}+05$ & 8.77E+05 & $\begin{array}{l}5.19 E+05(25 \mathrm{C}) \\
{[10]}\end{array}$ & ----- \\
\hline Carbon Disulfide & $4.70 \mathrm{E}+04$ & $8.19 E+04$ & $1 E+04(-10.9 C)$ & $1 \mathrm{E}+05(45.9 \mathrm{C})$ \\
\hline Acetone & $2.77 \mathrm{E}+04$ & $5.22 \mathrm{E}+04$ & $1 \mathrm{E}+04(1.3 \mathrm{C})$ & $1 \mathrm{E}+05(55.7 \mathrm{C})$ \\
\hline Methanol & $1.81 \mathrm{E}+04$ & $3.89 E+04$ & $1 \mathrm{E}+04\left(15.2^{\circ} \mathrm{C}\right)$ & $1 \mathrm{E}+05(64.2 \mathrm{C})$ \\
\hline Ethanol & $9.11 \mathrm{E}+03$ & $2.06 \mathrm{E}+04$ & $1 \mathrm{E}+04\left(29.2^{\circ} \mathrm{C}\right)$ & $1 \mathrm{E}+05(78.0 \mathrm{C})$ \\
\hline Glycolic acid & $5.10 \mathrm{E}+03$ & $1.05 E+04$ & ------------ & 1E5 (99 C) \\
\hline Isopropanol & $6.00 \mathrm{E}+03$ & $1.41 E+04$ & $1 \mathrm{E}+03(-1.3 \mathrm{C})$ & $1 \mathrm{E}+04\left(33.6^{\circ} \mathrm{C}\right)$ \\
\hline Formic acid & $4.82 \mathrm{E}+03$ & $1.02 E+04$ & $1 \mathrm{E}+03(-0.8 \mathrm{C})$ & $1 \mathrm{E}+04(37 \mathrm{C})$ \\
\hline Acetic acid & $1.77 \mathrm{E}+03$ & $4.21 E+03$ & $1 \mathrm{E}+03\left(14.2^{\circ} \mathrm{C}\right)$ & $1 \mathrm{E}+04(55.9 \mathrm{C})$ \\
\hline Morpholine & $1.26 \mathrm{E}+03$ & $2.95 E+03$ & $1 \mathrm{E}+02(21 \mathrm{C})$ & $1 \mathrm{E}+03(64.5 \mathrm{C})$ \\
\hline Ethoxyethanol & $8.87 \mathrm{E}+02$ & $2.31 E+03$ & $1 \mathrm{E}+02(-3 \mathrm{C})$ & $1 \mathrm{E}+03\left(30^{\circ} \mathrm{C}\right)$ \\
\hline Ethylmorpholine & $6.64 \mathrm{E}+02$ & $1.73 E+03$ & $\begin{array}{l}6.71 E+02(25 \mathrm{C}) \\
{[10]}\end{array}$ & 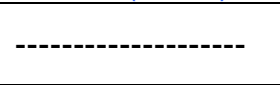 \\
\hline N-butanol & $5.99 \mathrm{E}+02$ & $1.67 E+03$ & $1 E+03\left(28^{\circ} \mathrm{C}\right)$ & $1 \mathrm{E}+04\left(64^{\circ} \mathrm{C}\right)$ \\
\hline Propanoic acid & $5.50 \mathrm{E}+02$ & $1.44 \mathrm{E}+03$ & $1 \mathrm{E}+02\left(0^{\circ} \mathrm{C}\right)$ & $1 \mathrm{E}+03(35.1 \mathrm{C})$ \\
\hline DMF & $4.29 \mathrm{E}+02$ & $1.06 \mathrm{E}+03$ & $1 \mathrm{E}+02\left(5^{\circ} \mathrm{C}\right)$ & $1 \mathrm{E}+03\left(38.0^{\circ} \mathrm{C}\right)$ \\
\hline Dibutylamine & $2.94 \mathrm{E}+02$ & $7.71 \mathrm{E}+02$ & $1 \mathrm{E}+02\left(10^{\circ} \mathrm{C}\right)$ & $1 \mathrm{E}+03\left(44^{\circ} \mathrm{C}\right)$ \\
\hline Diacetone alcohol & $2.04 \mathrm{E}+02$ & $5.80 E+02$ & $1 \mathrm{E}+02(13 \mathrm{C})$ & $1 \mathrm{E}+03\left(50.1^{\mathrm{C}} \mathrm{C}\right)$ \\
\hline N-butyric acid & $1.85 \mathrm{E}+02$ & $5.29 E+02$ & $1 \mathrm{E}+02(12.9 \mathrm{C})$ & $1 \mathrm{E}+03\left(52.2^{\circ} \mathrm{C}\right)$ \\
\hline Isobutyric acid & $1.81 \mathrm{E}+02$ & $5.23 E+02$ & $1 \mathrm{E}+02(18.1 \mathrm{C})$ & $1 \mathrm{E}+03\left(50.5^{\circ} \mathrm{C}\right)$ \\
\hline 2-butoxyethanol & $1.16 E+02$ & $3.31 E+02$ & $\begin{array}{l}1.17 E+02(25 \mathrm{C}) \\
{[10]}\end{array}$ & \\
\hline Ethoxyethoxyethanol & $2.49 \mathrm{E}+01$ & $8.11 E+01$ & $1 \mathrm{E}+02\left(40^{\circ} \mathrm{C}\right)$ & $1 \mathrm{E}+03\left(80.3^{\circ} \mathrm{C}\right)$ \\
\hline Propanediol & $2.44 \mathrm{E}+01$ & $9.13 E+01$ & $1 \mathrm{E}+01\left(13^{\circ} \mathrm{C}\right)$ & $1 \mathrm{E}+02\left(42^{\circ} \mathrm{C}\right)$ \\
\hline Valeric acid & $2.43 \mathrm{E}+01$ & $8.31 E+01$ & $1 \mathrm{E}+01\left(15.3^{\circ} \mathrm{C}\right)$ & $1 E+02\left(42.7^{\circ} \mathrm{C}\right)$ \\
\hline Acetylmorpholine & $1.77 \mathrm{E}+01$ & $5.23 \mathrm{E}+01$ & $\begin{array}{l}1.79 \mathrm{E}+01 \\
\left(25^{\circ} \mathrm{C}\right)\end{array}$ & $2.91 \mathrm{E}+01\left(50^{\circ} \mathrm{C}\right)$ \\
\hline Ethylene glycol & 1.10E+01 & $3.90 E+01$ & $1 \mathrm{E}+01(24 \mathrm{C})$ & $1 \mathrm{E}+02(51.1 \mathrm{C})$ \\
\hline Methylpyrrolidone & $1.01 \mathrm{E}+01$ & $3.38 \mathrm{E}+01$ & $1 \mathrm{E}+01(24 \mathrm{C})$ & $1 \mathrm{E}+02(53.1 \mathrm{C})$ \\
\hline Hexanoic acid & $5.40 \mathrm{E}+00$ & $2.08 \mathrm{E}+01$ & $1 \mathrm{E}+01\left(33^{\circ} \mathrm{C}\right)$ & $1 \mathrm{E}+02\left(59^{\circ} \mathrm{C}\right)$ \\
\hline Lactic acid & $3.76 \mathrm{E}+00$ & $1.56 \mathrm{E}+01$ & $3.81\left(25^{\circ} \mathrm{C}\right)$ & ----------- \\
\hline Butoxyethoxyethanol & $3.24 \mathrm{E}+00$ & $1.22 \mathrm{E}+01$ & $1 \mathrm{E}+00\left(14^{\circ} \mathrm{C}\right)$ & $1 \mathrm{E}+01\left(37^{\circ} \mathrm{C}\right)$ \\
\hline Ethyl hexanoate & $2.00 \mathrm{E}+00$ & $4.20 \mathrm{E}+00$ & -------------------" & $1 \mathrm{E}+03\left(108^{\circ} \mathrm{C}\right)$ \\
\hline Diethyl phthalate & $1.62 \mathrm{E}+00$ & $5.82 \mathrm{E}+00$ & $1 \mathrm{E}+00(12 \mathrm{C})$ & $1 \mathrm{E}+01(51 \mathrm{C})$ \\
\hline Caprolactam & 4.93E-01 & $1.96 \mathrm{E}+00$ & $1 \mathrm{E}+00\left(36.8^{\circ} \mathrm{C}\right)$ & $1 \mathrm{E}+01\left(58.9^{\circ} \mathrm{C}\right)$ \\
\hline Nonanoic acid & 1.17E-01 & 6.01E-01 & $1 E+00(48 \mathrm{C})$ & $1 \mathrm{E}+01(69 \mathrm{C})$ \\
\hline Urea & 1.56E-03 & $1.48 \mathrm{E}$ & $\begin{array}{l}1.6 \mathrm{E}-03(25 \quad \mathrm{C}) \\
{[10]}\end{array}$ & $2.1 \mathrm{E}-01\left(73^{\circ} \mathrm{C}\right)$ \\
\hline
\end{tabular}

\footnotetext{
${ }^{5}$ Unless otherwise indicated, these numbers come from reference [9].
} 


\subsection{Urine Wastewater}

To complete the analysis of what a ten-stage distillation column can separate effectively, the urine wastewater portion of the mixed stream is analyzed. The components to urine wastewater [2] are listed in Table $\mathrm{H}$ with their target concentrations. Of these sixteen components only four are not adequately separated from water through distillation with a ten-stage column.

\section{Table H: Components for Urine Wastewater Portion of the Mixed Stream (Humidity Condensate and Urine Wastewater)}

Note: The components written in red are not adequately separated from the water. The number of required stages is written in parentheses.

\begin{tabular}{|lclll|}
\hline \multicolumn{6}{|l}{ Component Mass Fraction } & & \\
\multicolumn{5}{|l}{} \\
& & [Feed] & [Distillate] & [Target] \\
Ammonia & $(1)$ & $2.11 \times 10^{-4}$ & $3.98 \times 10^{-38}$ & $5.0 \times 10^{-7}$ \\
Urea & $(2)$ & $5.76 \times 10^{-3}$ & $6.74 \times 10^{-49}$ & $5.76 \times 10^{-8}$ \\
Creatinine & $(2)$ & $7.68 \times 10^{-4}$ & $6.85 \times 10^{-43}$ & $7.7 \times 10^{-8}$ \\
Glucose & $(1)$ & $3.41 \times 10^{-3}$ & $4.15 \times 10^{-102}$ & $3.2 \times 10^{-7}$ \\
Citric Acid & $(1)$ & $3.45 \times 10^{-4}$ & $1.69 \times 10^{-79}$ & $1.8 \times 10^{-10}$ \\
Glutamic Acid & $(1)$ & $1.77 \times 10^{-4}$ & $9.18 \times 10^{-81}$ & $9.3 \times 10^{-8}$ \\
Lactic Acid & & $1.59 \times 10^{-4}$ & $1.79 \times 10^{-4}$ & $8.4 \times 10^{-8}$ \\
Phenol & $(3)$ & $1.26 \times 10^{-4}$ & $2.25 \times 10^{-16}$ & $1.17 \times 10^{-7}$ \\
Formic Acid & & $3.16 \times 10^{-5}$ & $3.52 \times 10^{-5}$ & $1.7 \times 10^{-8}$ \\
Oxalic Acid & $(1)$ & $1.51 \mathrm{e}-005$ & $1.58 \times 10^{-57}$ & $7.9 \times 10^{-9}$ \\
Hippuric Acid & $(1)$ & $7.36 \times 10^{-4}$ & $3.95 \times 10^{-63}$ & $3.9 \times 10^{-8}$ \\
Histidine & $(1)$ & $5.03 \times 10^{-5}$ & $4.17 \times 10^{-89}$ & $2.6 \times 10^{-8}$ \\
Taurine & $(1)$ & $2.25 \times 10^{-4}$ & $1.49 \times 10^{-42}$ & $1.2 \times 10^{-7}$ \\
Uric Acid & $(1)$ & $2.03 \times 10^{-4}$ & $1.59 \times 10^{-84}$ & $1.1 \times 10^{-7}$ \\
Methanol & & $4.45 \times 10^{-6}$ & $5.22 \times 10^{-6}$ & $4.2 \times 10^{-9}$ \\
Ethanol & & $5.58 \times 10^{-6}$ & $6.41 \times 10^{-6}$ & $5.2 \times 10^{-9}$ \\
\hline
\end{tabular}

As illustrated in Figure 22, the salts in urine wastewater will not be passed over to the distillate. These components require only one stage for separation from urine wastewater. The remaining components are shown in Table I. 


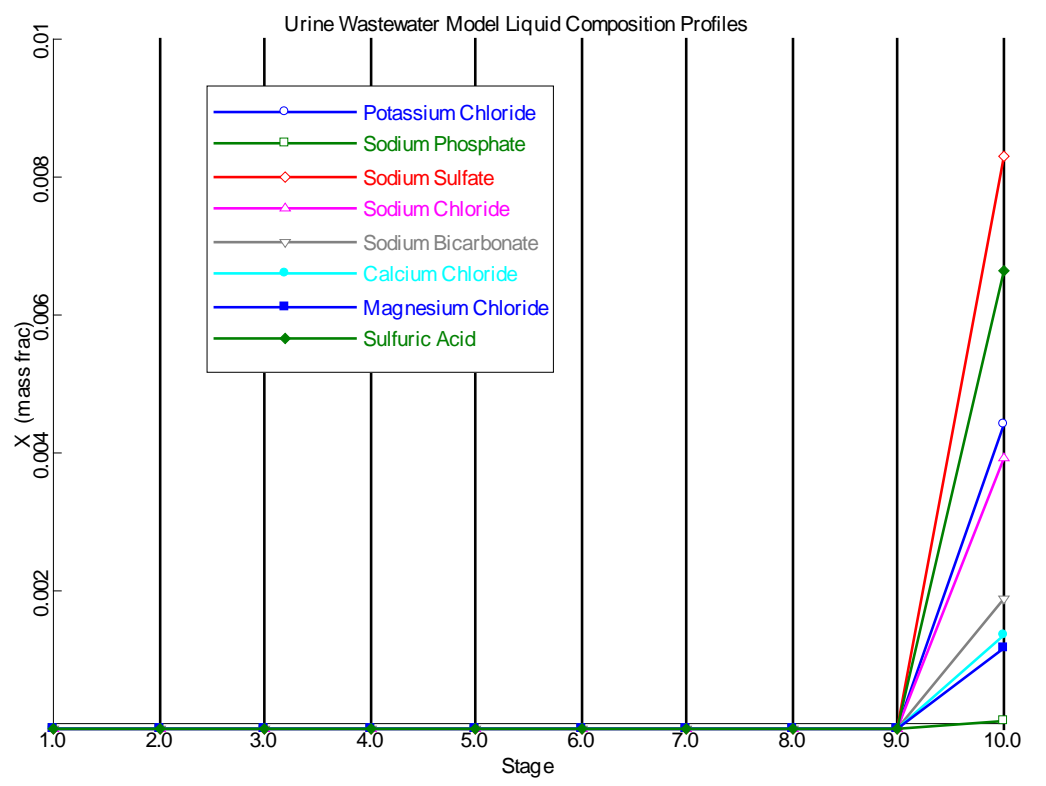

Figure 22: Liquid Composition Profile of the Salts from the Ten-Stage Urine Wastewater Model 
Table I: Components for Urine Distillation Modeling

Note: For samples of pretreated wastewater, 1-percent sulfuric acid is added as a component.

\begin{tabular}{|lrrr|}
\hline Urine Wastewater & $\begin{array}{c}\text { Pre-mixed } \\
\text { Concentration } \\
\text { [mg/L] }\end{array}$ & $\begin{array}{c}\text { Mixed } \\
\text { with HC- } \\
\text { Water } \\
\text { [mg/L] }\end{array}$ & $\begin{array}{c}\text { Target } \\
\text { Concentration } \\
\text { [mg/L] }\end{array}$ \\
Formic acid & 64 & 31.57 & 0.017 \\
Oxalic acid & 27 & 15.12 & 0.0079 \\
Citric acid & 79.3 & 345 & 0.00018 \\
Lactic acid & 369 & 159 & 0.084 \\
Uric acid & 471 & 203 & 0.11 \\
Taurine & 523 & 225 & 0.12 \\
Histidine & 1169 & 50.3 & 0.026 \\
L-glutamic acid & 412 & 177 & 0.093 \\
Hippuric acid & 1711 & 736 & 0.039 \\
Phenol & 292 & 126 & 0.117 \\
a-D-glucose & 7930 & 3410 & 0.32 \\
Creatinine & 1787 & 768 & 0.077 \\
Methanol & 5.1 & 4.45 & 0.0042 \\
Ethanol & 1.5 & 5.58 & 0.0052 \\
Urea & 13400 & 5760 & 54 \\
Sodium chloride & 1449 & 630 & 5.8 \\
Potassium sulfate & 2632 & 1145 & 11 \\
Potassium chloride & 1641 & 714 & 6.6 \\
Magnesium chloride & 431 & 187 & 1.7 \\
Calcium chloride & 498 & 217 & 2.0 \\
Potassium & & & \\
bicarbonate & 611 & 266 & 2.5 \\
Sodium sulfate & 3068 & 1335 & 12 \\
Sodium bicarbonate & 697 & 303.2 & 2.8 \\
Sulfuric acid & & 10700 & 0.9 \\
Sodium phosphate & 468 & 20 & 0.5 \\
Ammonia & 468 & 20 & \\
\hline
\end{tabular}

As illustrated in Figure 23, urea and creatinine reach their target concentrations after two stages. Under acidic conditions, the ammonia only requires one stage for separation. 


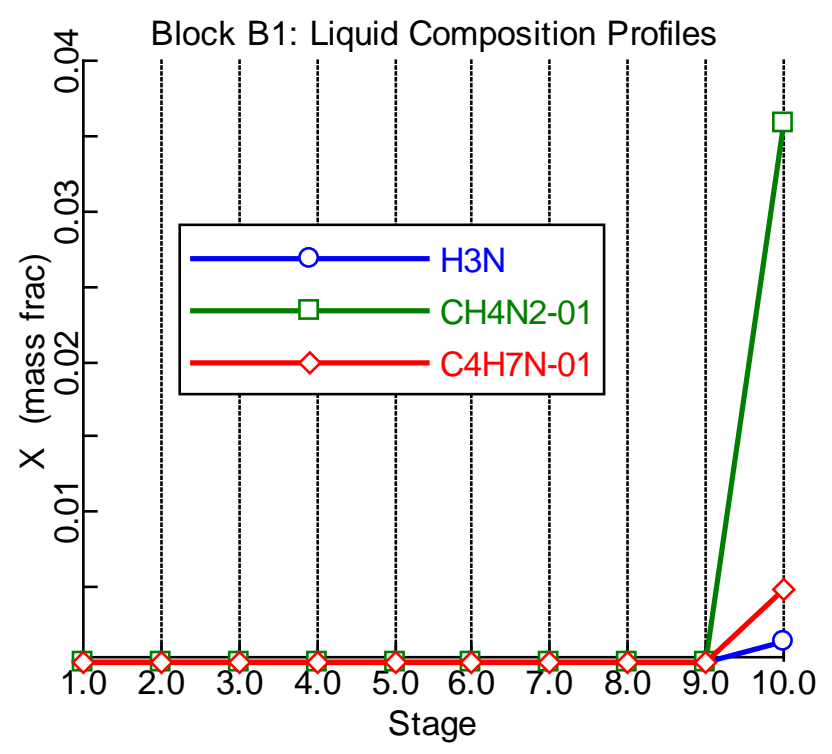

Figure 23: Liquid Phase Column Profile for Urea, Ammonia, and Creatinine

The estimated vapor pressures are recalled from the previous report (Development of Urine and Humidity Condensate Waste Water Feed Models for Water Recovery Processing Simulations) [2] as shown in Table J. The components written in blue are the components that cannot be adequately removed by a ten-stage distillation process where pure water is the distillate. However, the remaining components listed in the table can be separated by this method. From Table I and Figure 22, Figure 23, Figure 24, and Figure 25, it can be seen that for the components that can be separated, only a three-stage column is required to separate these compounds to give a high enough elimination. 


\begin{tabular}{|c|c|c|c|c|}
\hline Name & \multicolumn{2}{|c|}{ Estimated Values (Pa) } & \multirow{2}{*}{\multicolumn{2}{|c|}{$\begin{array}{l}\text { Literature Values }(\mathrm{Pa})^{n} \\
\text { Nearest Temperatures }\end{array}$}} \\
\hline & $25^{\circ} \mathrm{C}$ & $40^{\circ} \mathrm{C}$ & & \\
\hline Methanol & $1.81 E+04$ & $3.89 E+04$ & $1 \mathrm{E}+04\left(15.2^{\circ} \mathrm{C}\right)$ & $1 \mathrm{E}+05\left(64.2^{\circ} \mathrm{C}\right)$ \\
\hline Ethanol & $8.18 E+03$ & $1.88 \mathrm{E}+04$ & $1 \mathrm{E}+04\left(29.2^{\circ} \mathrm{C}\right)$ & $1 \mathrm{E}+05\left(78.0^{\circ} \mathrm{C}\right)$ \\
\hline Formic acid & $4.82 E+03$ & $1.03 E+04$ & $1 \mathrm{E}+03\left(-0 .{ }^{\circ} \mathrm{C}\right)$ & $1 \mathrm{E}+04\left(37^{\circ} \mathrm{C}\right)$ \\
\hline Phenol & $4.61 E+01$ & $1.41 E+02$ & $1 \mathrm{E}+01\left(9.6^{\circ} \mathrm{C}\right)$ & $2 \mathrm{E}+02(34.1 \mathrm{C})$ \\
\hline Lactic acid & $3.76 \mathrm{E}+00$ & $1.49 \mathrm{E}+01$ & $3.81(25 \mathrm{C})$ & -- \\
\hline Oxalic acid & 3.06E-02 & $2.07 \mathrm{E}-01$ & $3.12 \mathrm{E}-02\left(25^{\circ} \mathrm{C}\right)$ & -------------------- \\
\hline Creatinine & $2.84 \mathrm{E}-02$ & $1.60 \mathrm{E}-01$ & $2.89 \mathrm{E}-02\left(25^{\circ} \mathrm{C}\right)$ & -------------------- \\
\hline Taurine & $2.25 \mathrm{E}-02$ & $1.29 \mathrm{E}-01$ & $2.29 \mathrm{E}-02\left(25^{\circ} \mathrm{C}\right)$ & ------------------- \\
\hline Hippuric acid & 9.94E-05 & 7.59E-04 & 1.02E-04 (25 C) & --------------------- \\
\hline L-Glutamic acid & $2.20 \mathrm{E}-06$ & $3.13 E-05$ & $2.27 \mathrm{E}-06\left(25^{\circ} \mathrm{C}\right)$ & --------------------- \\
\hline Glycine & 1.67E-05 & $1.36 \mathrm{E}-04$ & $1.71 \mathrm{e}-05\left(25^{\circ} \mathrm{C}\right)$ & ------------------- \\
\hline Histidine & 7.78E-07 & 8.98E-06 & 7.99E-07 (25 C) & -------------------- \\
\hline Citric acid & 4.79E-07 & $7.41 \mathrm{E}-06$ & 4.9E-07 (25 C) & --------------------- \\
\hline Uric acid & $1.02 \mathrm{E}-07$ & $1.26 \mathrm{E}-06$ & $1.05 \mathrm{E}-07\left(25^{\circ} \mathrm{C}\right)$ & ------------------- \\
\hline Glucose & $5.79 \mathrm{E}-10$ & 1.31E-08 & $-\overline{-}^{-}$ & $2.6 \mathrm{E}-03\left(122^{\circ} \mathrm{C}\right)$ \\
\hline
\end{tabular}

Table J: Estimations of Vapor Pressure for Components in Urine Wastewater

Note: The components are presented from most volatile to least volatile. Those compounds with vapor pressures equal to or less than oxalic acid can be separated by the ten-stage column described in this section. These values were determined not only to rank the components in terms of volatility, but also to assess the accuracy of the PLXANTs calculated for the components [2].

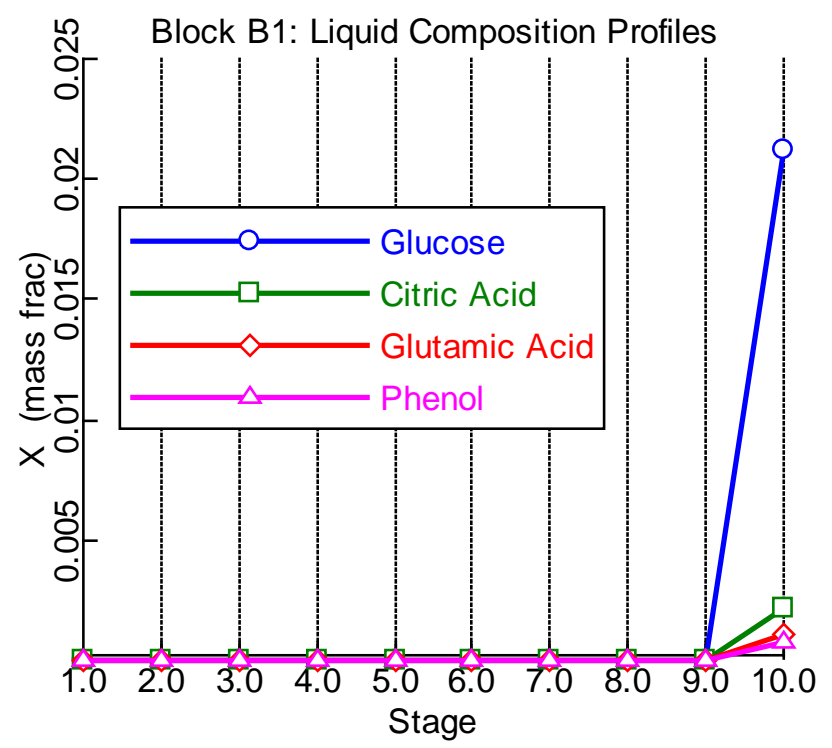

Figure 24: Liquid Composition Profile of Phenol, Glucose, Citric Acid, and Glutamic Acid 


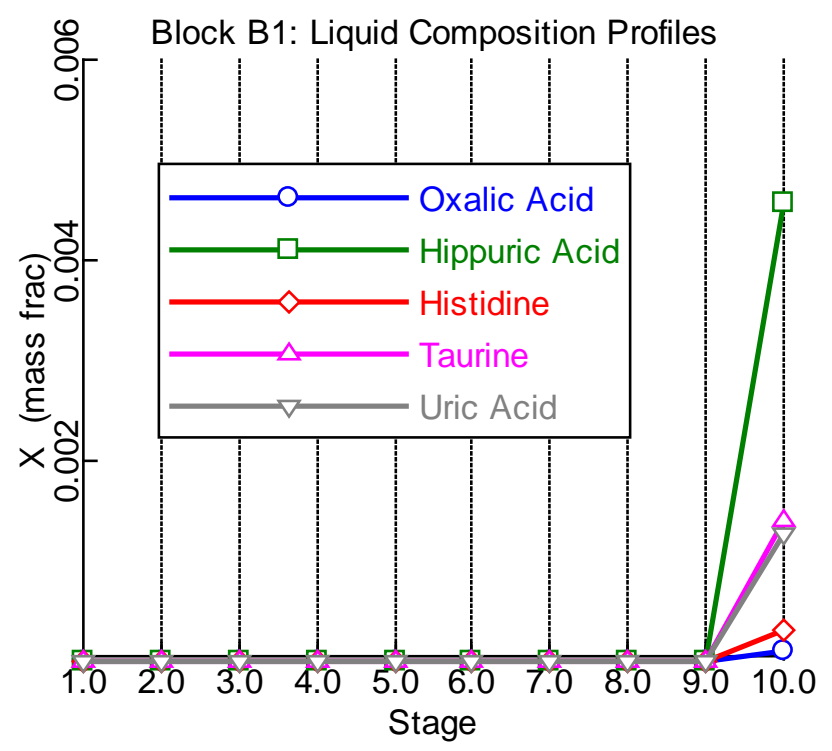

Figure 25: Liquid Composition Profile of Oxalic Acid, Hippuric Acid, Histidine, Taurine, and Uric Acid

\subsection{Distillation and Acetic Acid}

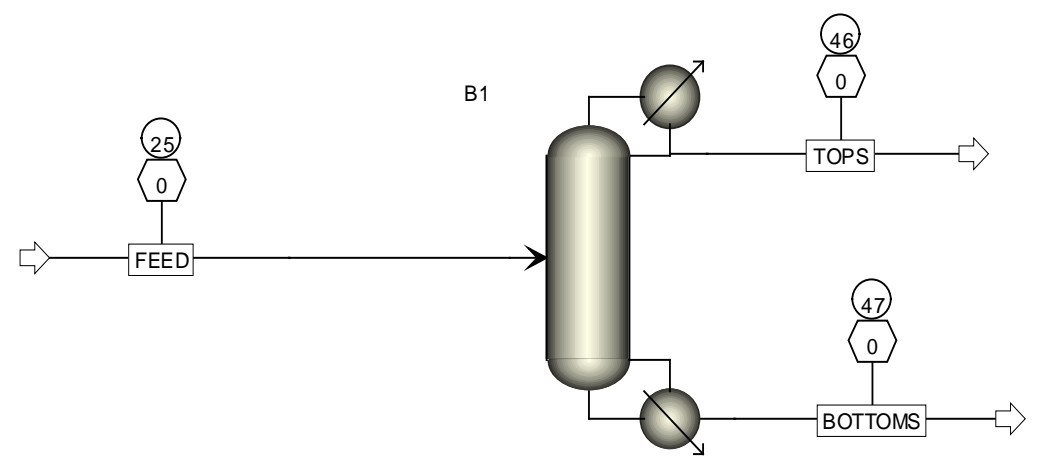

Figure 26: Scheme 2 - Distillation of Water with Acetic Acid

The values reported in the previous water report, Development of Urine and Humidity Condensate Waste Water Feed Models for Water Recovery Processing Simulations [2] for equilibrium constant and antoines coefficient where input into this model in Aspen (See Figure 26). When 0.01 mass fraction of sodium hydroxide $(\mathrm{NaOH})$ is added to a feed stream containing $8.18 \times 10^{-6}$ mass fraction of acetic acid, most of the acetic acid is deprotonated and exists as acetate with a sodium counter-ion (Table K). This species is particularly non-volatile. It is therefore worthwhile considering a distillation process for acetic acid in a distillation column to determine the feasibility of basic wastewater streams in water processing in gravitational environments. 


\begin{tabular}{|c|c|c|c|c|}
\hline & & Feed & Brine Water & Distillate \\
\hline pH & & 13.2 & 13.2 & 6.69 \\
\hline Temperature & ${ }^{\circ} \mathrm{C} 2$ & 25 & 46 & 47 \\
\hline Component & \multicolumn{4}{|c|}{ Mass Fraction } \\
\hline Water & & $9.90 \times 10^{-1}$ & $9.34 \times 10^{-1}$ & 1.00 \\
\hline Acetic Acid & & $1.94 \times 10^{-14}$ & $6.97 \times 10^{-14}$ & $3.33 \times 10^{-30}$ \\
\hline $\mathrm{Na}^{+}$ & & $5.75 \times 10^{-3}$ & $3.81 \times 10^{-2}$ & $1.28 \times 10^{-30}$ \\
\hline $\mathbf{H}_{3} \mathbf{O}^{+}$ & & $2.10 \times 10^{-15}$ & $2.60 \times 10^{-15}$ & $3.88 \times 10^{-9}$ \\
\hline $\mathbf{O H}^{-}$ & & $4.25 \times 10^{-3}$ & $2.82 \times 10^{-2}$ & $3.47 \times 10^{-9}$ \\
\hline $\mathrm{CH}_{3} \mathrm{CO}_{2}^{-}$ & & $3.04 \times 10^{-6}$ & $5.33 \times 10^{-5}$ & $1.03 \times 10^{-28}$ \\
\hline \multicolumn{5}{|l|}{ Vapor Pressure } \\
\hline $\mathrm{H}_{2} \mathrm{O}$ & Bar & $3.18 \times 10^{-2}$ & $1.05 \times 10^{-1}$ & $1.00 \times 10^{-1}$ \\
\hline Acetic Acid & Bar & $1.97 \times 10^{-2}$ & $6.18 \times 10^{-2}$ & $5.88 \times 10^{-2}$ \\
\hline
\end{tabular}

Table K: Output of the Basic Aspen Plus ${ }^{\circledR}$ Model Considering the Separation of Acetic Acid from Wastewater Under Basic Conditions

When the waste water contains 1-percent sulfuric acid, the results shown in Table $\mathrm{L}$ are obtained. There is little separation of acetic acid from the wastewater. Acetic acid is particularly difficult to remove from the water at low $\mathrm{pH}$. If an architecture is developed that employs an alkaline wastewater rather than an acidic wastewater feed, the problem of acetic acid removal may be solved without the need to move to ionexchange beds.

\begin{tabular}{|c|c|c|c|c|}
\hline & & Feed & Brine Water & Distillate \\
\hline pH & & 0.69 & 1.12 & 4.56 \\
\hline Temperature & & 25 & 46 & 46 \\
\hline Component & & \multicolumn{3}{|c|}{ Mass Fraction } \\
\hline Water & & $9.88 \times 10^{-1}$ & $9.23 \times 10^{-1}$ & 1.00 \\
\hline Acetic Acid & & $3.18 \mathrm{e} \times 10^{-6}$ & $2.91 \mathrm{e}-005$ & $2.63 \times 10^{-6}$ \\
\hline Sulfuric Acid & & $4.78 \times 10^{-13}$ & $2.84 \times 10^{-11}$ & $5.44 \times 10^{-30}$ \\
\hline $\mathrm{H}_{3} \mathrm{O}^{+}$ & & $2.40 \times 10^{-3}$ & $1.38 \times 10^{-2}$ & $5.25 \times 10^{-7}$ \\
\hline OH- & & $3.41 \times 10^{-15}$ & $8.41 \times 10^{-15}$ & $2.60 \times 10^{-11}$ \\
\hline $\mathrm{HSO}_{4}^{-}$ & & $7.56 \times 10^{-3}$ & $5.59 \times 10^{-2}$ & $5.39 \times 10^{-30}$ \\
\hline $\mathrm{CH}_{3} \mathrm{CO}_{2}^{-}$ & & $2.91 \times 10^{-9}$ & $8.30 \times 10^{-9}$ & $1.63 \times 10^{-6}$ \\
\hline $\mathrm{SO}_{4}{ }^{2-}$ & & $2.31 \times 10^{-3}$ & $7.09 \times 10^{-3}$ & $5.33 \times 10^{-30}$ \\
\hline \multicolumn{5}{|l|}{ Vapor Pressure } \\
\hline $\mathrm{H}_{2} \mathrm{O}$ & Bar & $3.18 \times 10^{-2}$ & $1.01 \times 10^{-1}$ & $1.00 \times 10^{-1}$ \\
\hline Sulfuric Acid & Bar & 4.79e $\times 10^{-8}$ & $4.14 \mathrm{e} \times 10^{-7}$ & $4.03 \times 10^{-7}$ \\
\hline
\end{tabular}

Table L: Output of the Basic Aspen Plus ${ }^{\circledR}$ Model Considering the Separation of Acetic Acid from Wastewater Under Acidic Conditions 


\section{Conclusions}

This article concerns distillation as a processing technique for the removal of contaminants from wastewater. Through distillation, it is observed that the higher molecular weight components such as hippuric acid and histidine are removed readily by a one-stage system. Other components, such as propionic acid require multiple stages for separation below their maximum tolerable levels. When the wastewater feed is acidic, the separation of organic acids such as acetic acid and formic acid becomes more difficult. Generally, a basic $\mathrm{pH}$ would allow for the effective separation of these components. On the other hand, ammonia is easily separated at acidic $\mathrm{pH}$, when it is predominantly in the form of ammonium ions. 


\section{Appendix}

\section{Contaminant Concentration Specifications}

Table A-1: Facility and Reclaimed Potable Water Quality Specification [10]

\begin{tabular}{|c|c|}
\hline Parameters & Specifications(a) \\
\hline \multicolumn{2}{|l|}{ Physical } \\
\hline $\begin{array}{l}\text { Total Solids } \\
\text { Color True } \\
\text { Taste } \\
\text { Odor } \\
\text { Particulates } \\
\text { PH } \\
\text { Turbidity } \\
\text { Dissolved Gas (1) } \\
\text { Free Gas (1) } \\
\end{array}$ & \begin{tabular}{|l|}
$100 \mathrm{mg} / \mathrm{l}$ \\
for reference only \\
for reference only \\
for reference only \\
40 microns (max size) \\
$4.5-8.5$ \\
$1 \mathrm{NTU}$ \\
(free at $37^{\circ} \mathrm{C}$ ) \\
(S.T.P.)
\end{tabular} \\
\hline \multicolumn{2}{|l|}{ Inorganics Constituents } \\
\hline $\begin{array}{l}\text { Ammonia } \\
\text { Arsenic } \\
\text { Barium } \\
\text { Cadmium } \\
\text { Calcium } \\
\text { Chlorine (total-includes chlo- } \\
\text { ride) } \\
\text { Chromium } \\
\text { Copper } \\
\text { lodine (total-includes organic } \\
\text { iodine) } \\
\text { Iron } \\
\text { Lead } \\
\text { Magnesium } \\
\text { Manganese } \\
\text { Mercury } \\
\text { Nickel } \\
\text { Nitrate ( } \mathrm{NO}_{3} \text { ) } \\
\text { Potassium } \\
\text { Selenium } \\
\text { Silver } \\
\text { Sulfate } \\
\text { Sulfide } \\
\text { Zinc }\end{array}$ & $\begin{array}{l}0.5 \mathrm{mg} / \mathrm{l} \\
0.01 \mathrm{mg} / \mathrm{l} \\
1.0 \mathrm{mg} / \mathrm{l} \\
0.005 \mathrm{mg} / \mathrm{l} \\
30 \mathrm{mg} / \mathrm{l} \\
200 \mathrm{mg} / \mathrm{l} \\
0.05 \mathrm{mg} / \mathrm{l} \\
1.0 \mathrm{mg} / \mathrm{l} \\
15 \mathrm{mg} / \mathrm{l} \\
0.3 \mathrm{mg} / \mathrm{l} \\
0.05 \mathrm{mg} / \mathrm{l} \\
50 \mathrm{mg} / \mathrm{l} \\
0.05 \mathrm{mg} / \mathrm{l} \\
0.002 \mathrm{mg} / \mathrm{l} \\
0.05 \mathrm{mg} / \mathrm{l} \\
10 \mathrm{mg} / \mathrm{l} \\
340 \mathrm{mg} / \mathrm{l} \\
0.01 \mathrm{mg} / \mathrm{l} \\
0.05 \mathrm{mg} / \mathrm{l} \\
250 \mathrm{mg} / \mathrm{l} \\
0.05 \mathrm{mg} / \mathrm{l} \\
5 \mathrm{mg} / \mathrm{l}\end{array}$ \\
\hline \multicolumn{2}{|l|}{ Bactericide } \\
\hline $\begin{array}{l}\text { Residual lodine (minimum) } \\
\text { Residual lodine (maximum) }\end{array}$ & \begin{tabular}{|l|}
$1 \mathrm{mg} / \mathrm{l}$ \\
$4 \mathrm{mg} / \mathrm{l}$ \\
\end{tabular} \\
\hline \multicolumn{2}{|l|}{ Aesthetics } \\
\hline $\mathrm{CO}_{2}$ & $15 \mathrm{mg} / \mathrm{l}$ \\
\hline \multicolumn{2}{|l|}{ Microbial } \\
\hline $\begin{array}{l}\text { Total count: } \\
\quad \text { Bacteria /Fungi } \\
\text { Total Coliform } \\
\text { Virus } \\
\end{array}$ & $\begin{array}{l}100 \mathrm{CFU} / 100 \mathrm{ml} \\
\text { Nondetectable } \\
\text { Nondetectable }\end{array}$ \\
\hline \multicolumn{2}{|l|}{ Organic Parameters (2) } \\
\hline $\begin{array}{l}\text { Total acids } \\
\text { Cyanide } \\
\text { Volatile organics }\end{array}$ & $\begin{array}{l}500 \text { micro gm/l } \\
200 \text { micro gm// } \\
\text { < EPA MCL per EPA method } \\
524.2 \text {, rev. } 4\end{array}$ \\
\hline $\begin{array}{l}\text { Semi-volatile organics } \\
\text { Total Alcohols } \\
\text { Total Organic Carbon (TOC) } \\
\text { Uncharacterized TOC (UTOC) (3) }\end{array}$ & $\begin{array}{l}<\text { EPA MCL per EPA method } 625 \\
500 \text { micro gm/l } \\
500 \text { micro gm/l } \\
\text { for reference only }\end{array}$ \\
\hline \multicolumn{2}{|c|}{$\begin{array}{l}\text { Notes: } \\
\text { (a) Maximum Contamination Level. } \\
\text { (1) No detectable gas using a volumetric gas vs. fluid measurement } \\
\text { system - excludes } \mathrm{CO}_{2} \text { used for aesthetic purposes. } \\
\text { (2) Each parameter/constituent maximum contamination level must be } \\
\text { considered individually and independently of others. } \\
\text { (3) UTOC equals TOC minus the sum of analyzed organic constituents } \\
\text { expressed in equivalent TOC. }\end{array}$} \\
\hline
\end{tabular}


Table A-2: Mixture of Humidity Concentrate and Urine Wastewater.

Note: A crew of four is anticipated to produce 6.0 kilograms (kg) of urine and $7.8 \mathrm{~kg}$ of humidity condensate per day. To this amount, 33.9 grams (g) of oxone and $14.7 \mathrm{~g}$ of sulfuric acid is added.

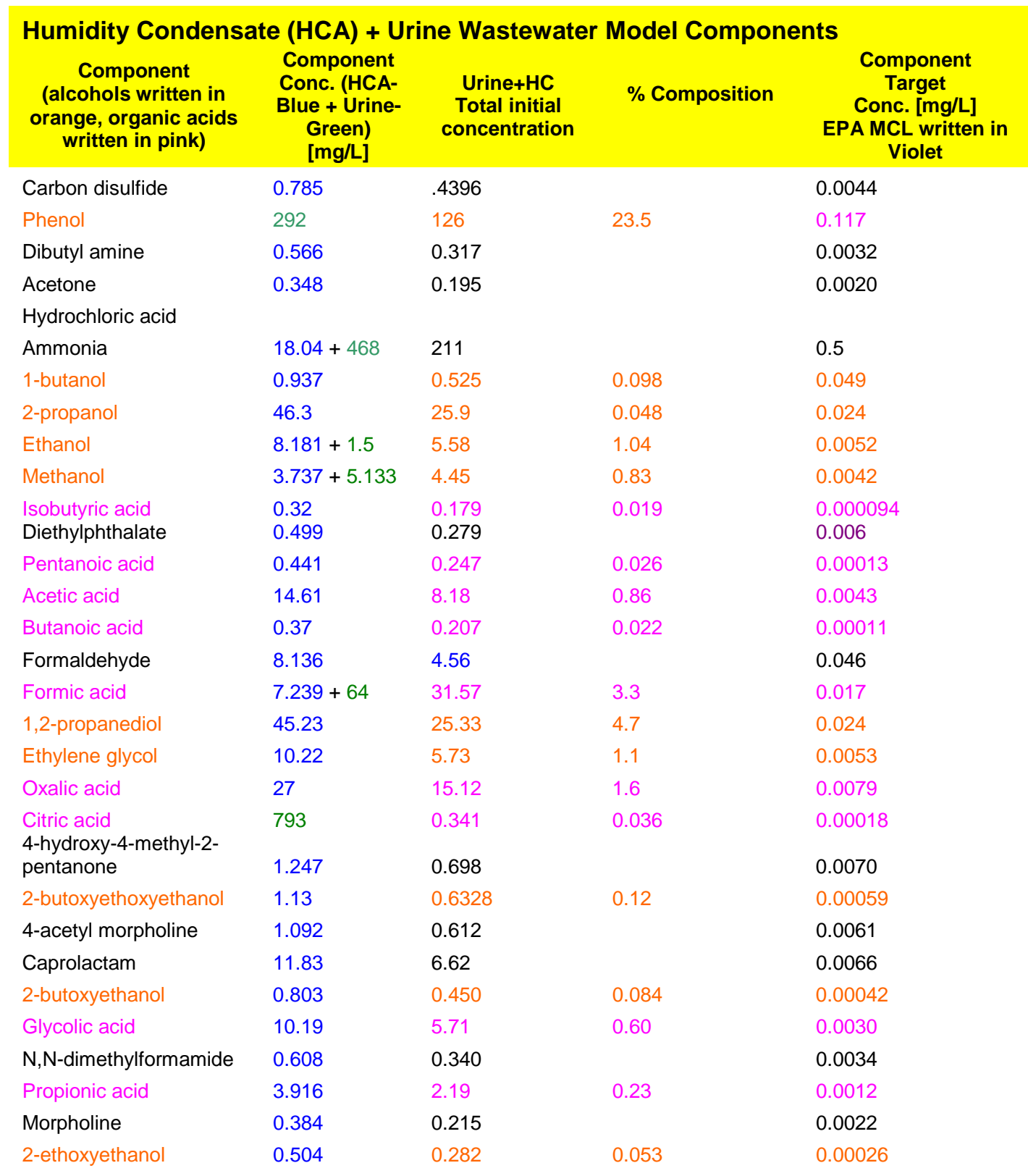


Table A-3: Mixture of Humidity Concentrate and Urine Wastewater (Continued from Table A-2)

Note: A crew of four is anticipated to produce $6.0 \mathrm{~kg}$ of urine and $7.8 \mathrm{~kg}$ of humidity condensate per day. To this amount, $33.9 \mathrm{~g}$ of oxone and $14.7 \mathrm{~g}$ of sulfuric acid is added.

\begin{tabular}{|c|c|c|c|c|}
\hline \multicolumn{5}{|c|}{ HCA + Urine Wastewater Model Components (cont.) } \\
\hline $\begin{array}{c}\text { Component } \\
\text { (alcohols written in } \\
\text { orange, organic acids } \\
\text { written in pink) }\end{array}$ & $\begin{array}{l}\text { Component } \\
\text { Conc. (HCA- } \\
\text { Blue + Urine- } \\
\text { Green) [mg/L] }\end{array}$ & $\begin{array}{c}\text { Urine+HC } \\
\text { Total initial } \\
\text { concentration }\end{array}$ & $\begin{array}{c}\% \\
\text { Composition }\end{array}$ & $\begin{array}{c}\text { Component } \\
\text { Target } \\
\text { Conc. [mg/L] } \\
\text { EPA MCL written } \\
\text { in Violet }\end{array}$ \\
\hline Lactic acid & & & & 0.084 \\
\hline 2-ethyl Hexanoic Acid & 0.37 & 0.207 & & 0.0021 \\
\hline 2-(2-ethoxyethoxy)ethanol & 0.354 & 0.198 & 0.037 & 0.00018 \\
\hline Hexanoic Acid & 0.582 & 0.326 & 0.034 & 0.00017 \\
\hline 1-methyl-2-pyrrolidinone & 0.339 & 0.190 & & 0.0019 \\
\hline Nonanoic acid & 0.335 & 0.188 & 0.019 & 0.0037 \\
\hline Taurine & 523 & 225 & 23.6 & 0.12 \\
\hline Histidine & 116.9 & 50.3 & 5.3 & 0.026 \\
\hline L-glutamic acid & 412 & 177 & 18.6 & 0.093 \\
\hline Hippuric acid & 171.1 & 73.6 & 7.7 & 0.039 \\
\hline$a-D$-glucose & 793 & 341 & 64 & 0.32 \\
\hline Creatinine & 1787 & 768 & & 0.077 \\
\hline 4-ethyl morpholine & 2.516 & 1.41 & & 0.014 \\
\hline Urea & $13400+2.415$ & 5760 & & 0.0576 \\
\hline Uric acid & 471 & 203 & 21 & 0.11 \\
\hline
\end{tabular}




\section{References}

[1] Trachtenberg, M.C.; Bao, L.; Goldman, S.L.; Smith, D.A. "Dynamic Maintenance of $\mathrm{CO}_{2}$ Levels in Closed Environments" ICES 2004-01-2376.

[2] Boul, P. "Development of Urine and Humidity Condensate Waste Water Feed Models for Water Recovery Processing Simulations” ESCG-4470-09-TEAN-DOC, 2009.

[3] Crenwelge, L.; McQuillan, J. “Exploration Life Support Water Recovery Test Plan” March 20, 2009.

[4] Carter, D. Layne "Waste Water Characterization for the ISS Water Processor." SAE Paper No. 981616. $28^{\text {th }}$ International Conference on Environmental Systems. Danvers, MA. July 13-16, 1998.

[5]"Introduction to Pinch Technology.” $\quad<$ http://www.ou.edu/class/che-design/adesign/Introduction\%20to\%20Pinch\%20Technology-LinhoffMarch.pdf>.

[6] Mujiburohman, M.; Sediawan, W.B.; Sulistyo, H. “A preliminary study: Distillation of isopropanol-water mixture using fixed adsorptive distillation method” Separation and Purification Technology, 48, 1, 85-92, 2006.

[7] Gangadwala, J.; Radulescu, G.; Kienle, A.; Sundmacher, K. "Computer aided design of reactive distillation processes for the treatment of waste waters polluted with acetic acid” Computers and Chemical Engineering 31, 1535-1547, 2007.

[8] Kister, Henry Z. Distillation Design McGraw Hill, Inc. 1992.

[9] Boul, P. "The Evaluation of Photocatalytic Oxidation and Thermal Catalytic Oxidation for a Trace Contaminant Control System” ESCG-4470-09-TEAN-DOC-0096, 2009.

[10] Carter, D.L.; Tabb, D.; Perry, J. “Performance Assessment of the Exploration Water Recovery System.” ICES 2008-01-0042. 